\title{
LA CIUDAD EN EL ESPEJO: HACIENDA MUNICIPAL E IDENTIDAD URBANA EN LA CATALUÑA BAJOMEDIEVAL
}

\author{
Pere Verdés Pijuan ${ }^{1,2}$ \\ IMF-CSIC (Barcelona)
}

\section{RESUMEN}

Tomando como pretexto la ciudad de Girona, este artículo pretende aproximarse al proceso de construcción de una identidad urbana en Cataluña durante la baja edad media a partir del análisis de la hacienda municipal. Habida cuenta de la práctica ausencia de estudios dedicados propiamente al tema así como su complejidad, se propone una primera reflexión general a partir del privilegiado observatorio que, tanto en el principado como en otros territorios y épocas, constituyen las finanzas públicas y la fiscalidad. Concretamente, a partir de la importante masa de trabajos dedicados a esta cuestión en Cataluña, se intenta mostrar como las incesantes demandas reales (y/o señoriales) y el consiguiente endeudamiento censal contribuyeron decisivamente a la configuración institucional del municipio y, por ende, al reforzamiento de la conciencia colectiva de la universitas. También se observa como la fiscalidad municipal en sus distintas modalidades se hizo cada vez más presente en la vida urbana, hasta el punto de convertirse en un elemento clave para la formulación del concepto de «ciudadanía» o de condicionar de forma importante el desarrollo urbanístico local.

1 Doctor en Historia. Científico Titular. Departamento de Estudios Medievales. Institució Milà i Fontanals. Consejo Superior de Investigaciones Científicas (CSIC). 08001. Barcelona. C.e.: pverdes@imf.csic.es.

2 Este artículo se inscribe en el proyecto de investigación «Monarquía, ciudades y elites financieras en la Cataluña bajomedieval» (HAR2008-04772/HIST), y se ha realizado en el marco del Grupo de Investigación Consolidado «Renda feudal i fiscalitat a la Catalunya baixmedieval» (2009 SGR 1367). 
Por último, se llama la atención sobre la progresiva importancia adquirida por la gestión del erario público en el «buen (o mal) gobierno» de la ciudad. Todo ello, a partir del análisis detallado de la dialéctica que se estableció entre el discurso, los símbolos e incluso los «rituales» de carácter fiscal y financiero así como del proceso de aculturación política experimentado por la población urbana en el principado a finales del periodo medieval.

Palabras clave: identidad urbana, bien común, fiscalidad, finanzas municipales, Cataluña, Girona, s. XIII-XV (o baja Edad Media).

\section{ABSTRACT}

Using as a pretext the city of Girona, this article seeks to examine the process of the construction of an urban identity in Catalonia during the later Middle Ages through an analysis of the municipal finances. Given the lack of studies dedicated directly to the theme, as well as its complexity, this study proposes an initial general reflection based on the privileged perspective provided by public finances and taxation, in the Principality as well as in other territories and periods. More specifically, on the basis of the significant amount of work dedicated to this question in Catalonia, the intention is to demonstrate how the unceasing demands by the crown (and / or the nobility) and the consequent census debt contribute decisively to the institutional configuration of the municipality and, thereby, to the strengthening of the collective conscience of the universitas. It will also be noted how the municipal taxation in its distinct modes became increasingly present in urban life, to the point of becoming a key element in the formation of the concept of 'citizenship', or of significantly conditioning local urban development. Finally, attention will be drawn to the progressive importance acquired by the financial administration in the «good (or bad) government» of the city. This will be done by means of a detailed analysis of the dialectic established between the discourse, symbols and the 'rituals' of fiscal and financial character and of the process of political acculturation experienced by the urban population in the Principality at the end of the medieval period.

Keywords: urban identity, common good, taxation, municipal finances, Catalonia, Girona, s. XIII-XV (or later Middle Ages).

\section{INTRODUCCIÓN}

El lunes 24 de septiembre del año 1498, entre las siete y las ocho de la madrugada, moría Francesc Boet, verguer (macero) municipal de Girona; «había sido un buen verguer -afirmaban los jurats-, descanse en paz». Así consta en el libro de actas municipales de dicha ciudad, donde al cabo de unos pocos días, el primero 
de octubre, ya aparece consignado el nombre de su sucesor, Guillem Serra. El nuevo verguer tomó posesión del cargo aquel mismo día y, al igual que Boet en 1484 y que el antecesor de este último en 1459, Serra recibió la orden de residir continuamente en la casa consistorial, previo inventario de boni et res dicte civitatis in domo concilii extantes ${ }^{3}$.

Gracias a este inventario de bienes municipales así como a los realizados anteriormente, en 1484 y en 1459, disponemos de una magnífica descripción de la Casa del Consell gerundense a finales de la edad media. Una secuencia de instantáneas, a través de la cuales desfilan ante nuestros ojos toda una serie de elementos que ilustran perfectamente el desarrollo institucional y, por ende, la conciencia política alcanzados por la ciudad en aquella época ${ }^{4}$.

La propia casa consistorial es uno de ellos, destacando entre sus diversas estancias las salas mayor y menor del consejo, el archivo y la capilla. En las salas mayor y menor del consejo, encontramos básicamente el mobiliario que permitía la reunión del principal órgano de decisión política de la ciudad, el Consejo ordinario, así como las actividades cotidianas de los distintos oficiales municipales. Además de los muebles, en los inventarios de estas dos salas también llama poderosamente la atención la significativa presencia del Dotzè del Crestià, de Francesc Eiximenis, encadenado a un

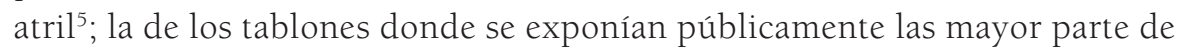
las ordenanzas que debían regir la actuación de los jurats, junto al calendario litúrgico (Compter); y, por último, la de una solitaria arca que guardaba todos los instrumentos de amortización de las rentas perpetuas (censales) vendidas por la ciudad.

3 Estos inventarios, procedentes de los libros de actas municipales o manuales negotiorum juratorum, fueron publicados por BATLLE Y PRATS, L., «Inventarios gerundenses del siglo XV», en Anales del Instituto de Estudios Gerundeses, 6, Girona 1951, pp. 179-192; IDEM, «La Casa del Concell de Gerona en 1498», en Anales del Instituto de Estudios Gerundeses, 17, Girona 1964-1965, pp. 373-381.

${ }^{4}$ Como se dice en la introducción de uno de los inventarios (1459), estos se realizaban ne bona, mobilia, amnesia, virge argentee, libri privilegiorum, tece sigillorum et privilegiorum, ornamentorum festivitatum, panni cum signis et vexillum et pennones, originalia mensurarum ac ponderum dicte civitatis et eius universitatis diminui valeant seu deperiri, qui ymo potius ad rei publice civitatis antefate utilitatem conservari... (BATLLE Y PRATS, «Inventarios municipales», p. 182). La puntuación del texto publicado ha sido revisada para mejorar su comprensión.

5 Esta referencia se halla en el inventario de 1498 y parece tratarse del incunable impreso en Valencia por Lamberto Palmart en 1484, conservado en el archivo de Gerona con anotaciones de los jurats hasta principios del s. XVII (BATLLE Y PRATS, «La Casa del Concell», p. 374). Véase la edición digital de esta obra impresa en http://bvpb.mcu.es/es/consulta/ registro. .cmd?id=406442. 
El resto de la documentación se hallaba en el archivo, donde destacaba la presencia de los pergaminos que contenían los privilegios de la ciudad, custodiados en un rico arcón cerrado con tres llaves, así como la de los libros «Verde» $\mathrm{y}$ «Rojo», en los que se copiaban dichas libertades junto a otros documentos de interés legal para el municipio ${ }^{6}$. Otras series que, convenientemente clasificadas y guardadas en sendos arcones, también merecían la atención explícita de los inventarios del verguer eran: los libros realizados para la audición de cuentas de la tesorería y otras administraciones municipales ${ }^{7}$; las cartas de procuración y las cuentas de los síndicos que habitualmente representaban a la comunidad; la documentación diversa generada por el hospital; la correspondencia y otras «escrituras» diversas, entre las cuales debían encontrarse -aunque no se diga- los libros de actas o manuales negotiorum juratorum ${ }^{8}$.Una mención a parte merecen los sellos «mayor» y «menor» de la ciudad así como todo el material relacionado con el proceso electoral del municipio, que -según los inventarios- también se custodiaban en el archivo municipal.

La capilla, construida durante la segunda mitad del s. XV, tan sólo aparece en el inventario de 1498 y contiene el mobiliario litúrgico habitual (crucifijos, misales, cálices...), incluyendo dos retablos dedicados a la Virgen y al arcángel San Miguel, custodio de la ciudad y patrón del oratorio municipal ${ }^{9}$. Repartida por las diferentes estancias (aunque concentrada, sobre todo, en el archivo) también hallamos toda la parafernalia relacionada con las solemnidades religiosas y profanas en las que participaba la institución municipal. Como acostumbraba a ser habitual en estos casos, destacaban todos aquellos objetos utilizados en las

6 Ambos cartularios han sido editados por la Fundación Noguera y el Ayuntamiento de Girona: GUILLERÉ, CH., Llibre Verd de la ciutat de Girona (1144-1533), Barcelona-Girona, 2000; JULIOL I ALBERTÍ, G., Llibre Vermell de la ciutat de Girona (1188-1624), Barcelona-Girona, 2001. Por lo que respecta a los pergaminos, los privilegios de la ciudad están incluidos dentro del catálogo general publicado por las mismas instituciones: Catàleg de pergamins del fons de l'Ajuntament de Girona (1144-1862), 3 vol., BarcelonaGirona, 2005.

7 Aunque no se diga explícitamente, dentro del arcón de retiments debían encontrarse también el resto de series fiscales y financieras que describe: GUILLERÉ, CH., «Les sources financières et fiscales de Gérone à la fin du Moyen Age», en D. Menjot- M. Sánchez (coord.) La fiscalité des villes au Moyen Age (France méridionale, Catalogne et Castille). 1. Étude des sources, Toulouse, 1996, pp. 45-56.

8 Al igual que los libros de privilegios, la correspondencia también ha sido editada por la Fundación Noguera y el Ayuntamiento de Girona: ARNALL I JUAN, M.J., Lletres reials a la ciutat de Girona (1293-1515), 2 vol., Girona-Barcelona, 2000.

9 En la autorización episcopal para construir la capilla, datada el 24 de junio de 1450, se decía que el permiso había sido solicitado porque sepius circa consevacionem rei publice occupati non valentes alias ecclesias et basílicas visitare in eadem capella prolixius orare et ipsas missas audire valeatis (BATLLE Y PRATS, «La Casa del Concell», p. 381). 
ceremonias reales (entradas, funerales, victorias...), además de los que servían para las fiestas del Corpus y del Ángel Custodio ${ }^{10}$.

También se guardaban en diferentes lugares los pesos y medidas de la ciudad: mientras que los patrones originales se encontraban en su mayor parte depositados en el archivo, el resto - incluyendo algunos instrumentos de medición (romanas)permanecía en las estancias situadas cerca de la entrada principal ${ }^{11}$. Algo similar sucedía con todo el arsenal del Consejo, que se encontraba fundamentalmente en la planta baja o en habitaciones secundarias de la casa consistorial. Este arsenal estaba compuesto por armas diversas (escudos, arcos, ballestas...) y, entre todo este armamento, cabe destacar las numerosas y diversas piezas de artillería (o armas de fuego) de que disponía la hueste de la ciudad, esto es, bombardas, bursots, espingardas y culebrinas con la correspondiente pólvora y munición. Las herramientas, utensilios y máquinas necesarias para la realización de obras públicas constituían otra de las categorías de objetos inventariados. Seguramente, la contratación de compañías especializadas y las prestaciones laborales debidas por los vecinos explican que el instrumental constructivo no sea excesivamente abundante en la casa, pese a lo cual existía un mínimo de material imprescindible para llevar a cabo dichos trabajos. Finalmente, en el inventario de 1484 también cabe destacar la existencia de una «sala del forment» así como de un «molino de sangre», integrado en el edificio. Al igual que en el caso de las obras públicas, esta mención resulta un tanto extraña, puesto que el municipio acostumbraba a recurrir al alquiler de almacenes y molinos privados, pero no deja de ser harto significativa de la preocupación de los jurats en aquellos años por el aprovisionamiento frumentario de la ciudad.

En otro orden de cosas, una última cuestión que llama poderosamente la atención cuando se leen los inventarios municipales es la omnipresencia de los símbolos reales y, sobre todo, de la ciudad. En efecto, las armas de la monarquía y de Girona están grabados, bordados o pintados en todo tipo de objetos: muebles, medidas, cirios, ropas, ornamentos, armas, libros... No obstante, tan sólo

${ }^{10}$ Cabe destacar que esta última festividad fue instituida por el municipio, en 1450, para conseguir la protección divina ante las pestes, terremotos y otras adversidades que pudieran afectar la ciudad. Sobre la capilla municipal y el establecimiento de la fiesta del Ángel Custodio, véase también la interesante información que ofrece: BATLLE Y PRATS, L., «La antigua capilla de San Miguel de la Casa de la Ciudad», en Anales del Instituto de Estudios Gerundenses, 20, Girona 1970-1971, pp. 317-355.

${ }^{11}$ Destaca la presencia, junto al original de la medida de capacidad utilizada en Gerona, de los originales de las que se utilizaban en S. Feliu de Guíxols, puerto natural de la ciudad, y en la de Barcelona, capital económica del principado. Sobre la administración municipal de estos pesos y medidas en Gerona, recuérdense también los detalles que ofrece otro artículo de BATLLE Y PRATS, L., «Pesos, mides i mesures de Girona en els segles XV i XVI», en Estudis dedicats a Ferran Soldevila en el seu 75 aniversari, II, Barcelona, 1970, pp. 103-107. 
me gustaría poner de relieve dos de estas manifestaciones heráldicas: por un lado, las diferentes banderas o estandartes de la ciudad, entre los cuales se distingue la que propiamente era de la comunidad, la que representaba a su veguería, la que se utilizaba para las ferias y la que encabezaba la hueste o sagramental; $y$, por otro lado, los blasones que aparecían en las vergues (mazas) y en la indumentaria de los verguers municipales, recordémoslo, inseparables acompañantes de los jurats en todo tipo de actos públicos y, en consecuencia, representación viviente de la institución municipal ${ }^{12}$.

\section{EL ESTUDIO DE LA IDENTIDAD URBANA: UNA VÍA DE APROXIMACIÓN}

A falta del correspondiente fresco alegórico sobre los efectos del buen y del mal gobierno en la ciudad, el retrato que nos ofrecen los inventarios de Girona bien podría dar pie -con todas sus limitaciones- a una completa reflexión sobre la identidad urbana en Cataluña durante el periodo bajomedieval ${ }^{13}$. Y es que el edificio consistorial constituye la manifestación arquitectónica por excelencia de la autonomía política de la ciudad, además de un espacio privilegiado donde convergen tanto los símbolos materiales como la documentación escrita (léase el discurso) que mejor pueden ilustrarnos sobre los valores compartidos, a finales de la edad media, por la comunidad local. Como acabamos de ver, la edilicia municipal, los órganos de gobierno, la religión cívica, la memoria archivística, la regulación comercial, la milicia urbana, las obras públicas, la asistencia hospitalaria, el abastecimiento frumentario y la simbología heráldica son algunos de los elementos representados en la Casa del Consell de Girona, que nos ofrecen un esbozo prácticamente integral de la imagen proyectada por la ciudad catalana a sus coetáneos durante el s. XV'14.

${ }^{12}$ Este cargo había sido creado el año 1351, cuando el rey Pedro el Ceremonioso (contemplacione dicte civitatis quam tanquam menbrum insigne principatus Cathalonie prerogativis fovere tenentur ac vestri dictorum iuratorum et proborum hominum predictorum, quos inter ceteros nostros subditos ad nostum movimos sempre ab experto anelare honorem) concedió a los jurats de la ciudad que certum nuncium seu certos nuncios habeatis qui cotidie discurrendo hinc inde... nunciaciones faciunt seu etiam mandamenta ad hoc ut dicti nuncio melius cognoscantur sollempniusque fiant nunciaciones predicte, dicti nuncio vestir virgas seu baculos infrascriptos de nostri licencia portare possent... (GUILLERÉ, Llibre verd, doc. 261).

${ }^{13}$ La alusión concreta al célebre fresco sienés responde a las interesantes reflexiones que, tomando como referencia dicha obra, realiza para el tema que nos ocupa: BOUCHERON, P. «Tournez les yeux pour admirer, vous qui exercez le pouvoir, celle qui est peinte ici. La fresque du Bon gouvernement d'Ambrogio Lorenzetti», en Annales. Histoire, Sciences sociales, 60, Paris 2006, pp. 1137-1199.

${ }^{14}$ Véase, por ejemplo, las inmensas posibilidades que ofrece tan sólo alguno de estos elementos en VIDAL FRANQUET, J., Les obres de la ciutat. L'activitat construtiva de la Universitat de Tortosa a la baixa edad mitjana, Barcelona, 2008. 
Ahora bien, pese a lo sugerente que pueda parecer un planteamiento de este tipo, actualmente resulta imposible determinar -si no es de forma, a mi entender, excesivamente epidérmica- la existencia de un «modelo de identidad urbana» en la Cataluña bajomedieval. Y, mucho menos, establecer cuáles fueron, cuándo aparecieron o cómo evolucionaron los principales rasgos que configuraban dicho modelo, contraponiendo las distintas percepciones que de él pudieron tenerse, según las diferentes realidades urbanas y los intereses económicos, políticos y sociales existentes en las ciudades y villas del país ${ }^{15}$.

Como puede suponerse, ello se debe básicamente a que, la historiografía catalana (o sobre Cataluña) todavía no ha reflexionado lo bastante sobre este complejo objeto de estudio y, en consecuencia, no disponemos de suficientes elementos de juicio para encauzar adecuadamente una síntesis sobre la cuestión de la identidad local en el principado a finales de la edad media ${ }^{16}$. Ciertamente, existen algunos estudios que pueden constituir interesantes puntos de partida para iniciar una reflexión que, por lo que respecta a la época moderna, ya ha suscitado un relativo interés ${ }^{17}$. Pero, incluso en este último caso, los historiadores

${ }^{15}$ Una interesante reflexión sobre el complejo tema de la identidad: PRODI, P. «Introduzione: evoluzione e metamorfosi delle identità collettive», en P. Prodi e W. Reinhard (ed.), Identità collettive tra Medioevo ed Età Moderna. Convengo Internazionale di Studio, Bolonia, 2002, pp. 9-27.

${ }^{16}$ No sucede lo mismo en otros territorios como Italia, Flandes o Alemania: BOONE, M. \& STABEL, P., Shaping urban identity inlate medieval Europe, Leuven-Apeldoorn, 2000; BOONE, M., LECUPRE-DESJARDIN, E. et SOSSON, J.P., Le verbe, l'image et les representations de la societé urbaine au Moyen Age, Anvers-Apeldoorn, 2002; CHITTOLINI, G. e JOHANEK, P. (a cura di), Aspetti e componenti dell'identità urbana in Italia e in Germania (secoli XIV-XVI), Bolonia, 2003. También pueden encontrarse interesantes aproximaciones al tema en Castilla: véase, por ejemplo, el reciente trabajo de JARA FUENTE, J.A., «Percepción de si, percepción del otro: la construcción de identidades urbanas en Castilla (el concejo de Cuenca en el siglo XV)» en Anuario de Estudios Medievales, 40/1, Barcelona 2010, pp. 75-92.

${ }^{17}$ Para la época medieval, tan sólo un estudio ha sido dedicado propiamente al tema de la identidad urbana en Cataluña: DAILEADER, P., De vrais citoyens: violence, mémoire et identité dans la communauté médiévale de Perpignan (1162-1397), Canet, 2004 (=True citizens: violence, memory, and identity in the medieval community of Perpignan, 1162-1397, Leiden, 2000). De todas formas, son diversos los investigadores que, de una u otra manera, han reflexionado al respecto, destacando entre todos ellos F. Sabaté: entre sus muchos trabajos sobre temas relacionados con la identidad urbana, véanse por ejemplo las síntesis más recientes (con la bibliografía que incluyen) SABATÉ CURULL, F., «La civiltà comunale del medioevo nella storiografia spagnola: affinità e divegenze», en A. Zorzi (ed.), La civiltà comunale italiana nella storiografia internazionale. Atti del convegno internazionale di studi (Pistoia, 9-10 aprile 2005), Firenze, 2008, pp. 117-162; «Estamentos, soberanía y modelo político en la Cataluña bajomedieval», en Aragón en la Edad Media, XXI, Zaragoza 2009, pp. 245-278. 
modernistas consideran el bagaje de las investigaciones claramente insuficiente si lo que se pretende es ofrecer una panorámica completa sobre la identidad local en el principado ${ }^{18}$. Ante esta tesitura, y para no caer en una simple enumeración de tópicos comunes a cualquier ciudad del occidente medieval, he optado por abordar la cuestión de la identidad urbana desde un ángulo concreto, el de la hacienda municipal, con el fin de profundizar mínimamente en el tema y, de esta manera, ofrecer algunas hipótesis que pueden resultar útiles para una futura síntesis general.

Además de la experiencia personal con que cuento en este campo concreto de investigación, tres son las principales razones que justifican la elección de mi objeto de estudio: en primer lugar, el considerable volumen de trabajos dedicados en Cataluña, directa o indirectamente, a las finanzas locales, lo cual nos proporciona suficientes elementos para reflexionar sobre la cuestión con ciertas garantías ${ }^{19}$; en segundo lugar, la innegable trascendencia de la materia fiscal en sí misma, considerada tradicionalmente, tanto por historiadores como por economistas y sociólogos, como «espejo» de la sociedad ${ }^{20} ; \mathrm{y}$, por último, el probado interés que, junto a otros elementos, ya ha demostrado tener la hacienda municipal para el estudio de la progresiva

18 Véanse, por ejemplo, las opiniones al respecto del máximo especialista en el tema: AMELANG, J.S., «Cities: identities, conflicts, solidarities», en IV Congrés Internacional d'Història Local de Catalunya. El cor urbà dels conflictos: identitat local, consciència nacional i presència estatal, Barcelona, 1999. Remito también a otro trabajo más reciente, centrado en el caso de Barcelona, así como a la bibliografía que contiene: SIMON TARRES, A. , «La identitat de Barcelona i els barcelonins a l'època moderna», en Manuscrits, 19, Barcelona 2001, pp. 137-153.

${ }^{19}$ Me remito únicamente a algunas de las monografías más recientes, que incluyen una extensa bibliografía sobre el tema: ORTÍ GOST, P., Renda i fiscalitat en una ciutat medieval: Barcelona, segles XII-XIV, Barcelona, 2000; MORELLÓ BAGET, J., Fiscalitat i deute públic en dues viles del Camp de Tarragona. Reus i Valls, segles XIV-XV, Barcelona, 2001; VERDÉS PIJUAN, P., «Per ço que la vila no vage a perdició»: la gestió del deute públic en un municipi català (Cervera, 1387-1516), Barcelona, 2004.

${ }^{20}$ Desde que J.A. Schumpeter afirmara que «nothing shows so clearly the character of a society and of a civilization as does the fiscal policy that its political sector adopts», la fiscalidad ha sido considerada por innumerables autores como un observatorio privilegiado para el estudio de las relaciones económicas, sociales y políticas en cualquier sociedad (SCHUMPETER, J.A., SCHUMPETER, E.B, History of economic análisis, London, 1994 (1954), p. 736). En nuestro caso concreto, y para evitar una relación interminable de citas, me remito tan sólo a las interesantes reflexiones que realiza A. Grohmann al respecto, en un reciente trabajo donde, entre otras cosas, leemos que «il tema della fiscalità è uno di quegli ambiti di recerca tramite i quali è possibile indagare sul complesso dell'evoluzione della società, delle sue forme di potere, delle sue lotte egemoiche» (A. GROHMANN, «La fiscalità nell'economia europea, secc. XIII-XVIII», en S. Cavaciocchi (a cura di), La fiscalità nell'economia europea, secc. XIII-XVIII. Fiscal systems in the European economy from the $13^{\text {th }}$ to the $18^{\text {th }}$ centuries, Firenze, 2008, pp. 5-48. 
configuración de una identidad urbana en otros territorios del Occidente bajomedieval ${ }^{21}$.

Con estas premisas, y partiendo de las tesis que avalan el papel de las finanzas municipales en los orígenes y la progresiva construcción de la institución municipal en Cataluña, me propongo reflexionar aquí sobre el grado de cohesión que pudo proporcionar también la hacienda a la comunidad urbana medieval ${ }^{22}$. Como ya he apuntado, esta idea no es ni mucho menos nueva pero sí que puede resultar relativamente original el intento de demostrar que algunas de las hipótesis tradicionalmente planteadas por economistas, sociólogos e historiadores en el estudio de la llamada «fiscalidad de Estado» (republicanismo, ciudadanía fiscal, «gobernanza»...) pueden resultar asimismo fértiles si se aplican al caso de la ciudad medieval, siendo además especialmente pertinentes para el caso catalán ${ }^{23}$.

Efectivamente, desde mediados del s. XIII, el desarrollo político de las comunidades urbanas en el principado así como el de su conciencia colectiva parece haber estado profundamente marcado por la cuestión hacendística. Y, en mi opinión, tres son los argumentos principales que apoyarían esta hipótesis: en primer lugar, el papel catalizador desempeñado por las demandas reales/señoriales (y el consiguiente endeudamiento censal) en el proceso de consolidación institucional del municipio; en segundo lugar, la creciente importancia adquirida por la fiscalidad municipal en la vida urbana, sobre todo en la de los «ciudadanos» o «vecinos» del lugar; y, finalmente, la trascendencia que, como consecuencia de todo lo anterior, acaba teniendo la administración financiera en el ejercicio del «buen (y mal) gobierno» de la ciudad.

Como veremos a continuación, el análisis de estas tres cuestiones nos permitirá observar cómo las autoridades locales fueron capaces de formular y articular progresivamente un elaborado discurso destinado a justificar la política fiscal y

${ }^{21}$ Véase, por ejemplo: BOUCHERON, P., «Les enjeux de la fiscalité directe dans les communes italiennes (XIIIe-XVe siècles), en D. Menjot y M. Sánchez (coord.), La fiscalité des villes au Moyen Âge (Occident méditerranéen). 2. Les systemes fiscaux, Toulouse, 1999, pp. 153-167; SHILLING, H., «Identità repubblicane nell'europa della prima età moderna. L'esempio della Germania e dei Paesi Bassi», en P. Prodi y W. Reinhard (a cura di), Identità collettive tra Medioevo ed Età Moderna. Convegno Internazionale di Studio, Bolonia, 2002, pp. 241-264; BOONE, M., «Les anciennes démocraties des Pays-Bas? Les corporations flamantes au bas Moyen Age (XIVe-XVIe siècles): intérêts économiques, enjeux politiques, identités culturelles urbaines», en Atti dello XX Convegno internazionale di studi 'Tra economia e politica: le Corporazioni nell'Europa medievale, Pistoia, 2007, pp. 187-228.

${ }^{22}$ Las hipótesis a las que me refiero han sido formuladas, sobre todo, por M. Turull y P. Ortí. Véase, por ejemplo, ORTí GOST, P., «El Consell de Cent durant l'Edat Mitjana», en Barcelona. Quaderns d'Història, 4, Barcelona 2001, pp. 21-48; TURULL RUBINAT, M., «Nuevas hipótesis sobre los orígenes de los concejos municipales en Cataluña (siglos XIIXIII): algunas reflexiones», en Anuario de Historia del Derecho Españo, 72, Madrid 2002, pp. 461-471.

${ }^{23}$ Una primera muestra de ello, en DAILEADER, De vrais citoyens, esp. 27-48. 
financiera del consistorio. Un discurso que estuvo presidido por la omnipresente idea tomista del «bien común», y que se apoyó en todo el arsenal teórico proporcionado por los juristas y los teólogos de la época, especialmente por aquellos pertenecientes a las órdenes mendicantes ${ }^{24}$. Asimismo, y al igual que sucedió en otros ámbitos del gobierno municipal, el estudio de dichas cuestiones nos mostrará cómo los regidores se sirvieron de diversos elementos simbólicos e incluso «rituales» para reforzar sus argumentos. Todo ello con el propósito de movilizar de forma efectiva la afección ciudadana (o evitar la desafección), especialmente en el contexto de los numerosos conflictos que enfrentaron al Consejo (o a quienes lo dirigían en cada momento) con sus distintos interlocutores fiscales y financieros.

\section{LA CIUDAD EN EL ESPEJO FISCAL}

Iniciemos, pues, nuestra reflexión que tomará como pretexto la ciudad de Girona y, más concretamente, los inventarios de su casa consistorial. Como decía, estos sugerentes documentos ofrecen toda una serie de testimonios que, directa o indirectamente, nos permiten introducirnos en el estudio del proceso de construcción de un «modelo de identidad urbana» en Cataluña a finales de la época medieval. Y, entre todos estos testimonios, también hallamos una magnífica «piedra de toque» para poner a prueba algunas de las hipótesis que planteo sobre el papel jugado por la hacienda municipal en dicho proceso: me refiero, al ejemplar del Dotzè del Crestià de Francesc Eiximenis que, en 1498, encontramos en la sala mayor del consejo, encadenado a un atril para su pública consulta2.

${ }^{24}$ Especialmente útiles para aprehender el «hilo rojo» de los argumentos que configuran y dan coherencia al discurso sobre la identidad política en el principado son los trabajos de: EVANGELISTI, P., I Francescani e la costruzione di uno Stato. Linguaggi politici, valori identitari, progetti di governo in area catalano-aragonese, Padova, 2006; «Il valore di Cristo. Lautocomprensione della comunità politica in Francesc Eiximenis», en Enrahonar, 42, Barcelona 2009, págs. 65-90.

${ }^{25}$ Como es sabido, esta obra constituía, junto al Regiment de la Cosa Pública y el Libre de Regiment de Prínceps (ambas contenidas también en el Dotzè) y a la Doctrina Compendiosa (de autor anónimo), una lectura habitual para muchos sectores de la población urbana en Cataluña durante el s. XV, y por tanto un referente obligado para conocer el discurso político de la época (IGLÉSIAS i FONSECA, J.A., Llibres i lectors a la Barcelona del s. XV. Les biblioteques de clergues, juristes, metges i altres ciutadans a través de la documentació notarial (anys 1396-1475), Tesis doctoral inédita, Universidad Autónoma de Barcelona, 1996, http://www.tesisenxarxa.net/TDX-0418108-171750/; HERNANDO DELGADO, J., «Obres de Francesc Eiximenis en biblioteques privades de la Barcelona del segle XV», en Arxiu de Textos Catalans Antics, 26, Barcelona 2007, pp. 385-568). Sobre las tesis del franciscano en relación a la hacienda pública, analizo con más detalle su obra en: VERDÉS PIJUAN, P., «Fiscalidad urbana y discurso franciscano en la Corona de Aragón (s. XIV-XV)», en M.C. Giannini, Fiscalità e religione nell'Europa cattolica: teorie, linguaggi e pratiche (secoli XIV-XIX), título provisional de la obra en prensa. 


\subsection{Las demandas reales (o señoriales) y el endeudamiento censal}

Car dit és damunt que sens gran necessitat, notòria e evident, qui vinga a la cosa pública sens colpa del princep, lo dit príncep no pot prendre de sos súbdits ultra les rendes acostumades e, si u fa, torna de senyor natural ver tiran ${ }^{26}$. Esta es una idea que, de forma mucho más desarrollada, se repite hasta la saciedad en el Dotzè del Crestià, así como en otras obras de la misma época donde la «libertad» fiscal de la ciudad constituye un valor fundamental ${ }^{27}$.

Evidentemente, según Francesc Eiximenis, el príncipe tenía la potestad de cobrar tributos, e incluso se hacía hincapié en la necesidad de que dispusiera de suficientes recursos para ejercer correctamente sus labores de gobierno así como para mantener la dignidad real ${ }^{28}$. Pero las demandas extraordinarias del monarca no podían tener un carácter arbitrario, sino que debían atenerse solamente a determinadas circunstancias y realizarse en el marco establecido por las asambleas generales o Cortes $^{29}$. Fiel a su estilo pedagógico, el franciscano recurre a elocuentes ejemplos situados en un espacio y tiempo imaginarios para formular sus tesis, apuntando también la posibilidad de que, en caso de recaudar unilateralmente nuevos tributos, el rey pudiera ser incluso depuesto por sus súbditos. Y ello porque tal hecho se consideraba como un grave atentado contra la «cosa pública», además de una ruptura del compromiso de fidelidad mutua que se debían el príncipe y la comunidad ${ }^{30}$.

Durante el s. XV, las autoridades locales del país debían tener muy presentes las opiniones del franciscano u otras de carácter similar. No obstante, esta línea de argumentos, que tan ligada ha estado tradicionalmente con la imagen de la ciudad catalana medieval, no era de ninguna manera consubstancial a su iden-

${ }^{26}$ EIXIMENIS, F., Dotzè llibre del Crestià, Girona, 1986- 2005, vol. II, 2, cap. 677.

${ }^{27}$ E notats ací que jatsia fer mal o dan en tant o en quant o en qualque manera a la cosa pública sie cosa molt greu e desplaent a Déu, emperò notablement en dues coses, de les quals vos guardats axí com de foc cremant. La una és enginyar o tenir manera o conservar, per propri profit o per altra rao, que blats o altres viandes se encaresquen; car açò és dretament matar la pobre gent. La segona és fer o consentir o dar lloc que novell o no acostumat victigal o càrrec, gran ne poc, sia posat a la gent en profit de la senyoria (EIXIMENIS, F., Doctrina Compendiosa, Barcelona, 1929, pp. 123-124). De haber sido realmente de F. Eiximenis, también podría haber empezado este apartado con este contundente texto de la Doctrina Compendiosa, en el que el anónimo fraile de la obra se dirigía a los regidores urbanos para equiparar la contribución señorial al más nefando de los agios.

${ }^{28}$ También se insistía en que el soberano administrase de forma cuidadosa el patrimonio «con que había sido dotado por la comunidad», recomendándole además que se rodease de buenos oficiales y actuase conforme a las virtudes políticas habituales (EIXIMENIS, Dotzè, I, 1, cap. 421431; II, 1, cap. 502, 524...). Véase también: EIXIMENIS, Dotzè, I, 1, cap. 193; II, 2, cap. 677.

${ }^{29}$ EIXIMENIS, Dotzè, II, 1-II, 2, cap. 669-675.

${ }^{30}$ EIXIMENIS, Dotzè, I, 1, cap. 124-125; II, 1, cap. 606; II, 2, cap. 677; EIXIMENIS, F., Regiment de la cosa pública, Barcelona, 1927, cap. 15 
tidad, sino el fruto de una larga evolución histórica en que la contribución a las demandas reales (y/o señoriales) había jugado un papel fundamental.

Seguramente, los jurats gerundenses eran perfectamente conscientes de este hecho y, en nuestro caso, tan sólo hace falta repasar la cronología de los libros de privilegios de la ciudad para darse cuenta de ello: de los 585 documentos consignados en estos cartularios medievales, 18 son anteriores al 1300 y 150 al 1400, lo que significa que 407 documentos (70\%), muchos de ellos libertades urbanas fundamentales, corresponden al s. XIV ${ }^{31}$. Como puede suponerse, esta circunstancia no es en absoluto casual y responde, tanto en Girona como en otras poblaciones reales (y también señoriales), a la frenética dinámica fiscal y financiera que tuvo lugar durante dicha centuria ${ }^{32}$.

Tal como también puede inferirse de la documentación conservada, aquella dinámica se había iniciado ya durante el s. XIII, cuando la próspera comunidad urbana en Cataluña se convirtió en la principal interlocutora fiscal de la Corona (o del señor). Entre otros motivos, fue para facilitar este diálogo que dicha comunidad vio reconocida su personalidad jurídica como universitas por el poder real (o señorial), con la consiguiente carga jurídica que dicho término conllevaba. La necesidad de organización institucional que exigían las crecientes demandas reales y/o señoriales también contribuyó decisivamente a que el Consell, entendido como órgano de decisión política de la universidad, cristalizara definitivamente. Y, finalmente, otra de las consecuencias lógicas de la dinámica fiscal iniciada en el doscientos fue la consolidación definitiva de una «arca común» y de unos recursos fiscales (tallas o derramas) comunitarios ${ }^{33}$.

${ }^{31}$ Más datos sobre el contenido concreto de estos cartularios en las respectivas introducciones de la edición, especialmente en la del libro rojo (nota 6).

${ }^{32}$ Para el caso de Girona, véase el estudio más reciente de GUILLERÉ, Ch., «La fiscalité d'une ville catalane à travers la correspondance royale (XIIIe-XVe siècles), en M. Sánchez y D. Menjot (dir.), Fiscalidad de Estado y fiscalidad municipal en los reinos hispánicos medievales, Madrid, 2006, pp. 317-333. Para el resto del realengo catalán, me remito a M. SÁNCHEZ MARTÍNEZ, M. y ORTI GOST, P., «La Corona en la génesis del sistema fiscal municipal en Catalunya (1300-1360)», en M. Sánchez y A. Furió (ed.), Corona, municipis i fiscalitat a la baixa Edat Mitjana, Lleida, 1997, pp. 233- 278; ORTI GOST, P., «La distribución de la carga fiscal entre las ciudades y villas de realengo en la Cataluña del siglo XIV», en Ibídem, pp. 275-316.

${ }^{33}$ Vid. nota 22. También se profundiza en todas estas cuestiones en el estudio VERDÉS PIJUAN, P. y TURULL RUBINAT, M., «Els municipis catalans a l'època de Jaume I», que aparecerá próximamente en el volumen del Congreso conmemorativo del VIII centenario del nacimiento del rey Jaume I, dedicado a El poder reial. Les institucions. La politica internacional. En este trabajo, completamos para Cataluña la extensa relación ya presentada por J.A. Barrio sobre las primeras meciones a universitas en el principado (BARRIO BARRIO, J.A. «La introducción del término «universitas» en las instituciones municipales del Reino de Valencia», en Actas do IV Congresso Internacional do Latim Medieval Hispanico, Lisboa, pp. 191-201). Para citar sólo 
En el caso concreto de Girona, documentamos por primera vez el término universitas el año 1263, en un documento de Jaime I donde se establecía equivalencias monetarias precisamente pro solucione tributorum et censualium ${ }^{34}$. Y en 1284 , casi un siglo después del fallido intento de creación de un Consulado ${ }^{35}$, se documenta la autorización real para que pudieran ser elegidos sex probi homines... quolibet anno pro gubernanda ipsa civitate. Una autorización que, no debe olvidarse, aparece al final de un extenso privilegio real, cuyo principal objetivo era regular la percepción de tallas en la ciudad así como su correcta administración ${ }^{36}$.

Ahora bien, a la luz de los estudios actuales, todavía no podemos determinar con seguridad cuál fue el resultado exacto de la dialéctica inicial que se estableció, a lo largo del s. XIII, entre la dinámica fiscal y el imaginario colectivo a la hora de configurar una identidad urbana en Cataluña. Lo único que parece claro, parafraseando a P. Ortí, es que los regidores de aquella época todavía no vestían las vistosas gramallas del s. XV $\mathrm{XV}^{37}$, y que pasarían todavía bastantes años hasta que no se edificara la casa consistorial, se creara su archivo, se construyera la capilla o se pintaran los retablos de la Virgen o el del Ángel Custodio. Y, mientras tanto, se produjo una secuencia de hechos fundamental: el incremento espectacular de las demandas reales y la consiguiente entrada en escena del endeudamiento municipal a largo plazo ${ }^{38}$.

Este binomio probablemente constituyó uno de los mayores «catalizadores» que hasta entonces había conocido la comunidad y, como manifestación signi-

algúnos ejemplos precoces, mencionar los casos de Bagà (1234), Tortosa (1238), Perpinyà (1242), Barcelona (1243), Balaguer (1244), Tarragona (1246), Montblanc (1246), Palau-delVidre (1246), Vic (1257), Cervera (1258), Millàs (1260), Manresa (1262), Colliure (1263), Cambrils (1263), Girona (1263), Vilafranca de Conflent (1264), Puigcerdà (1264), Torroella de Montgrí (1265), Tàrrega (1274), Salses (1274), Gandesa (1275)...

${ }^{34}$ BARRIO, «La introducción del término», p. 199, cf. HUICI MIRANDA, A. y CABANES PECOURT, M.D., Documentos de Jaime I de Aragón, Zaragoza, 1976-1988, vo. 5, doc. 1353.

${ }^{35}$ Sobre el interesante fenómeno -también desde el punto de la identidad urbana- de las primeras «confraries» y «consolats» en Cataluña, véase por ejemplo: TURULL RUBINAT, M., La configuració jurídica del municipi baix-medieval. Règim municipal i fiscalitat a Cervera entre 1182-1430, Barcelona, 1990, pp. 93-119; GOURON, A., «Les consuls de Barcelona en 1130: la plus ancienne organisation municipale a l'Ouest des Alpes?», en Anuario de Historia del derecho Español, 60, Madrid 1991, pp. 205-214; DAILEADER, Ph., «The Vanishing Consulates of Catalonia», en Speculum, 74, Lugar 1999, pp. 65-94.

${ }^{36}$ GUILLERÉ, Llibre Verd, pp. 46-49.

${ }^{37}$ ORTÍ, «El Consell de Cent...», pp. 23.

${ }^{38}$ En este punto, cabe recordar que, de acuerdo con sus postulados «mercantilistas», Francesc Eiximenis no era partidario de la emisión de rentas por parte de las ciudades, puesto que ello suponía -según él- inmovilizar capital necesario para la actividad comercial. Debe advertirse, sin embargo, que Eiximenis no era contrario ni mucho menos a dichas formas de crédito, tal como puede observarse en su Tractat d'usura. No obstante, en la delicada coyuntura financiera de finales del s. XIV, consideraba que existían mejores opciones para hacer frente a las ineludibles necesidades comunitarias (EIXIMENIS, Dotzè, I, 1, cap. 152). 
ficativa de este hecho, recordemos por un momento la solitaria caja de rentas redimidas que se hallaba en la sala (menor) del consejo gerundense. Aunque se trate de una mera suposición, no resultaría descabellado pensar que en dicha arca se encontraban todavía muchas de las rentas perpetuas (censales) y vitalicias (violarios) vendidas por el municipio desde mediados del s. XIV. Unas rentas que-como ya he apuntado- permitieron hacer frente a las enormes peticiones de numerario realizadas por la Corona durante el trescientos, y gracias a las cuales se consiguieron la mayor parte de privilegios de la universidad ${ }^{39}$.

Como es sabido, la petición anual de la questia (que muchas veces también incluía un subsidio extraordinario) había supuesto ya un paso importante hacia la configuración institucional del municipio ${ }^{40}$. No obstante, acabó siendo el alud de peticiones extraordinarias de la Corona que se produjo en el dominio real a partir de 1321 y en todo el principado a partir de 1356 el que aceleró definitivamente el proceso de consolidación política y financiera de la institución local ${ }^{41}$. La convocatoria ininterrumpida de Cortes y Parlamentos para financiar las guerras mediterráneas y la posterior contienda con Castilla obligaron a realizar un extraordinario esfuerzo económico a las ciudades y villas del país, que todavía fue mayor cuando la amenaza de compañías mercenarias forzaron la reforma de las fortificaciones urbanas y las graves carestías frumentarias hicieron imprescindible la intervención municipal para garantizar el abastecimiento de cereal ${ }^{42}$.

${ }^{39}$ Para el endeudamiento municipal de la ciudad de Girona, véase una primera aproximación en GUILLERÉ, Ch., «Fiscalité et societé à Gerone au XIVe siècle», en M. Sánchez y A. Furió (ed.), Corona, municipis i fiscalitat a la baixa Edat Mitjana, Lleida, 1997, pp. 381-382. Y sobre el progresivo reforzamiento de las libertades urbanas, véase: FERNÁNDEZ I TRABAL, J., Una familia catalana medieval. Els Bell-lloc de Girona (1267-1533), Barcelona, 1995, pp. 83-100 (esp. 91-92).

40 SÁNCHEZ MARTíNEZ, M., «Tributos negociados: las questies/subsidios de las villas catalanas en la primer mitad del siglo XIV», en Anuario de Estudios Medievales, 38/1, Barcelona 2008, pp. 65-99 (esp. 72-73). A propósito de todo el «ritual» que acompañaba la petición, negociación y concesión del tributo, véase un ilustrativo ejemplo en SÁNCHEZ MARTÍNEZ, M., «Fiscalidad real y villas en Cataluña: de la ordenación del subsidio a su liquidación (el ejemplo de la questial subsidio de 1338 y la villa de Cervera», en M. Sánchez y D. Menjot (coord.), La fiscalité des villes au Moyen Âge (Occident méditerranéen). 4. La gestion de l’impôt, Toulouse, 2004, pp. 93-94.

${ }^{41}$ Ejemplos del resultado que también tuvo esta dinámica en las poblaciones de señorío catalanas: SÁNCHEZ MARTÍNEZ, M., «Fiscalidad y finanzas de una villa señorial catalana: Castelló d'Empúries, 1381-1382», en M. Sánchez (ed.), Fiscalidad real y finanzas urbanas en la Cataluña Medieval, Barcelona, 1999, pp. 301-362; GALERA PEDROSA, A., «Endeutament i fiscalitat senyorial a la Catalunya del segle XV. El cas del comtat de Cardona (1419-1433)», en Ibídem, pp. 363-391 (esp. pp. 369-379); MORELLÓ, Fiscalitat i deute públic, pp. 89-200.

${ }^{42}$ Por lo que respecta al proceso de endeudamiento en otras ciudades y villas, tanto reales como señoriales, del principado, me remito a las contribuciones más recientes (así como la bibliografía que contienen) publicadas en SÁNCHEZ MARTÍNEZ, M. (ed.), La deuda pública en la Cataluña bajomedieval, Barcelona, 2009. 
En este contexto de urgencia, las autoridades locales observaron como los expedientes financieros utilizados hasta entonces resultaban claramente insuficientes, razón por la cual no tuvieron otro remedio que recurrir a la emisión de rentas perpetuas y vitalicias en nombre de la universidad ${ }^{43}$. Seguramente, muchos de los instrumentos de procuración que también se guardaban en uno de los arcones del archivo de Girona correspondían al nombramiento, realizado en el marco de un consejo general, de los síndicos encargados de vender los censales o violarios en nombre de «toda» la universidad. Y es que, tal como puede leerse en estos documentos (en las posteriores cartas de venta o en otras fuentes coetáneas), eran todos los cabezas de familia de la comunidad los que firmaban, de forma física o por representación legal, el documento de procuración, constituyéndose solidariamente en deudores y poniendo su persona y la totalidad de sus bienes como garantía de la operación ${ }^{44}$.

No cabe duda de que estas multitudinarias reuniones para nombrar síndicos así como los posteriores compromisos contractuales adquiridos por el conjunto de los vecinos contribuyeron de forma importante al aumento de la conciencia colectiva de la universidad. Y, seguramente, también reforzaron este sentimiento las dificultades que se documentan en algunas localidades, a finales del s. XIV, a la hora de hacer frente a los intereses de una deuda devenida casi crónica. En efecto, muchas de las acciones emprendidas por los acreedores contra los municipios deudores se dirigían contra intereses particulares y, cuando ello no era posible, se recurría a las penas religiosas, llegándose incluso a la excomunión general de la comunidad. El discurso elaborado durante esta época para justificar los atrasos e implorar clemencia, para solicitar la intercesión del rey (o del señor) o para reprochar a los acreedores su falta de paciencia e incluso su crueldad constituyen una buena muestra del incremento progresivo de la conciencia colectiva. Como también lo constituyen la actitud y las palabras pronunciadas por los regidores de aquellos lugares donde residían los acreedores, siempre dis-

${ }^{43}$ Cabe destacar el papel de la monarquía a la hora de incentivar también las primeras emisiones de rentas en muchas poblaciones del realengo, incluida Girona, tal como demuestra SÁNCHEZ MARTíNEZ, M., «La Corona en los orígenes del endeudamiento censal de los municipios catalanes (1343-1344)», en M. Sánchez y D. Menjot (dir.), Fiscalidad de Estado y fiscalidad municipal en los reinos hispánicos medievales, Madrid, 2006, pp. 241-247.

${ }^{44}$ Todas estas garantías contractuales así como la posterior repercusión que podían tener han sido descritas por RUBIO MANUEL, D., «L'estructura diplomàtica dels censals morts i els violaris», en J. Serrano (ed.), El territori i les seves institucions històriques, vol. II, Barcelona, 1999, pp. 843-863; SABATÉ CURULL, F., «La insolvència municipal a la segona meitat del s. XIV», en M. Sánchez (ed.), Fiscalidad real y finanzas urbanas en la Cataluña medieval, Barcelona, 1999, pp. 264-278. Véanse también algunos ejemplos concretos de toda la secuencia de documentos generados por la emisión de rentas en el apéndice de SÁNCHEZ, La deuda pública, pp. 335-461. 
puestos a defender los derechos de sus conciudadanos por considerarlos como parte del interés general de la universidad ${ }^{45}$.

Llegados a este punto, los planteamientos de Eiximenis empiezan a cobrar sentido, como también lo hacen las palabras de los síndicos enviados por las ciudades y villas del realengo a las Cortes y Parlamentos convocados, a finales del s. $\mathrm{XIV}$, por el rey. Efectivamente, tras haber conseguido muchos de sus privilegios, la voz de estas poblaciones (o la de sus experimentados dirigentes) empieza a oírse cada vez con mayor claridad, reclamando sus exenciones fiscales y oponiéndose, a finales de dicha centuria, prácticamente a cualquier demanda real ${ }^{46}$. El extremo endeudamiento y, en consecuencia, la supervivencia de sus respectivas comunidades justificaban perfectamente esta posición, máxime cuando aquella pesada carga había sido contraída en su mayor parte para «servir» a la Corona o para hacer frente a necesidades inexcusables de la comunidad. Nada podía reprochárseles, por tanto, y el sacrificio realizado durante tantos años les permitía incluso erigirse como garantes de los intereses del realengo y, por extensión, de la cosa pública del principat ${ }^{47}$. Como digo, desde finales del s. XIV, esta fue la actitud habitual de los procuradores municipales en Cortes, que seguían

45 Tras la contribución pionera de F. Sabaté (citada en la nota anterior), esta cuestión ha merecido la atención de diversos historiadores, que nos ofrecen una completa panorámica de los problemas financieros provocados por la deuda a largo plazo tanto en las localidades del realengo como en las de señorío: MORELLÓ, Fiscalitat i deute públic, pp. 873-893; VERDÉS PIJUAN, P., «Per ço que la vila no vage a perdició»: la gestió del deute públic en un municipi català (Cervera, 1387-1516), Barcelona, 2004; MORELLÓ BAGET, J., Municipis sota la senyoria dels creditors de censals: la gestió del deute públic a la baronia de la Llacuna (segle XV), Barcelona, 2008; MARTÍ ARAU, A., «Endeutament censal i crisi financera a una vila senyorial: Castelló d’Empúries (1381-1393)», en M. Sánchez, La deuda pública, pp. 153-217; GALERA PEDROSA, A., «Endeutament censal, pressió fiscal i alçaments populars (el cas del comtat de Cardona i la Vall de Lord a mitjan segle XV)», en Ibídem, pp. 309-331.

${ }^{46}$ Seguramente, el estudio que mejor permite apreciar el progresivo cambio de actitud de las ciudades y villas del realengo y, en general, de los tres brazos que componían las asambleas de Cortes ante las demandas de la Corona sea el de SÁNCHEZ MARTíNEZ, M., «Las Cortes de Cataluña en la financiación de la Guerra de Arborea (segunda mitad del siglo XIV)», en M.T. Ferrer, J. Mutgé, M. Sánchez (eds.), La Corona Catalanoaragonesa i el seu entorn mediterrani a la baixa Edat Mijana, Barcelona, 2005, pp. 363-393.

${ }^{47}$ Recordemos, en este sentido, el texto del célebre memorial valenciano presentado a Juan I, donde se le reprochaba que, por culpa de los malos consejeros, hubiera gastado hasta el último dinero de sus rentas ordinarias y que havets a viure de fiscalies e plor de vostres gents sin tener en cuenta el gran cargo que ante Dios esto suponía y el peligro de perder el mayor tesoro que tuviera rey en el mundo, esto es, la fidelidad y el corazón de sus súbditos. Véase el original de este texto así como otros datos que ilustran perfectamente la creciente tensión vivida entre la monarquía y las villas y ciudades de sus estados en el clásico trabajo de FERRER MALLOL, M.T., «El patrimoni reial i la recuperació dels senyorius jurisdiccionals en els estats catalano-aragonesos a la fi del segle XIV», en Anuario de Estudios Medievales, 7 , Barcelona 1970-1971, pp. 351-491 (esp. 353). 
la estela de Barcelona y de otras grandes ciudades para negarse, apelando al bien común, a satisfacer cualquier donativo que no fuera otorgado de forma general por el conjunto de los brazos ${ }^{48}$.

Sin duda, este discurso reflejaba en gran medida la realidad, tal como lo demuestran los problemas financieros e incluso la ruina de algunos municipios catalanes por razón de la deuda ${ }^{49}$. No obstante, cabe preguntarse hasta qué punto el dramático panorama que nos pintan las fuentes municipales no respondía también a una estrategia del municipio (y/o de sus clases dirigentes) para preservar sus intereses. No en vano, después de superar las dudas planteadas por la venta de las primeras rentas, las autoridades locales se habían lanzado a una desenfrenada carrera de emisiones y no sólo eso, sino que también se opusieron (en algún caso con éxito) a los sucesivos intentos de la monarquía para controlar la capacidad de endeudamiento municipal ${ }^{50}$. Según los procuradores urbanos, los Consejos estaban suficientemente capacitados para decidir por sí mismos lo que más convenía a su respectivas universidad; lo cual era cierto, pero no excluía el claro interés general que existía por parte del municipio así como el interés particular de muchos de sus miembros por conservar -dentro de unos límites razonables- la deuda censal ${ }^{51}$.

${ }^{48}$ Analizo con detalle la estrategia fiscal y el discurso formulado por las autoridades de la villa de Cervera durante el s. XV en VERDÉS PIJUAN, P., «Atès que la utilitat de la universitat deu precehir lo singular: discurso fiscal e identidad política en Cervera durante el s. XV», en Hispania (en prensa).

${ }^{49}$ Vid. nota 45.

${ }^{50}$ Tras la prohibición de 1363, el año 1376, documentamos una tentativa por parte de las ciudades y villas del realengo de recuperar el control sobre la emisión de rentas. Los representantes de estos lugares, asistentes a las Cortes de Monzón, manifestaron ante el rey que la venta de censales y violarios era la mejor forma de hacer frente a las necesidades de sus respectivas comunidades, entre las cuales destacaban las obras de las murallas, el abastecimiento frumentario y otros gastos. No obstante, según los síndicos, el control real obstaculizaba el buen funcionamiento de las haciendas municipales, razón por la cual solicitaban al monarca que les retornase la capacidad de emitir rentas libremente; car pensar pot, senyor, la vostra altesa que.Is de cascuna ciutat, vila e loch, sabents lurs facultats pròpries, mils que altre no faran les dites vendes sinó per lo menor dampnatge e per lo milor bé lur. El rey rechazó la propuesta pero autorizó, nuevamente, la venta de censales siempre que estos sirvieran para amortizar rentas más onerosas o bien para la construcción de las murallas (SÁNCHEZ MARTÍNEZ, Manuel; ORTÍ, Pere. Corts, parlaments i fiscalitat a Catalunya: els capitols del donatiu (1288-1384), Barcelona, 1997, pp. 515-516).

${ }^{51}$ En vez de remitirme a la larga lista de estudios (muchos de ellos, citados en notas anteriores) que demuestran los evidentes intereses que tenían las oligarquías urbanas catalanas en la deuda municipal, prefiero mencionar un elocuente acuerdo del Consell de la ciudad de Barcelona tomado en 1433, donde el castigo impuesto a un grupo de ciudadanos rebeldes consistió en la inmediata amortización de todos los censales municipales que poseían y en la prohibición de comprar nuevas rentas de la ciudad, directa o indirectamente (BATLLE GALLART, C., La crisis social y económica de Barcelona a mediados del siglo XV, vol. I, Barcelona, 1973, pp.139). 
Consciente de este hecho, la monarquía no se resignó sin más a la negativa de las autoridades locales a satisfacer sus demandas y, durante el último tercio del s. XIV, inició lo que podría considerarse como un verdadero asedio fiscal contra los municipios catalanes, especialmente de realengo ${ }^{52}$. En este conflictivo contexto, a lo largo de todo el s. XV, acabó de reforzarse la identidad política de las comunidades urbanas frente a la autoridad superior real/señorial, alcanzando de nuevo su máxima expresión en el marco del contundente discurso municipal utilizado para resistir los envites de los comisarios del monarca. Ante la negativa municipal a contribuir en las asambleas generales o de forma particular, el rey enviaba sus representantes a las ciudades y villas del país, aprovechando cualquier excusa para intervenir en la vida municipal. Como mínimo, esta es la imagen que pretendían transmitir en muchas ocasiones las autoridades municipales, que negaban (como veremos más adelante) todas las acusaciones formuladas contra ellos y las presentaban, en la mayoría de los casos, como violaciones de sus libertades particulares así como de las leyes del principado. El recurso a la fuerza por parte de los representantes reales no hacía sino deslegitimar las demandas del monarca, presentadas a menudo como dañinas extorsiones a la res pública local. Y la estrategia de desprestigio utilizada por los regidores municipales se completaba con la atribución de todo tipo de vicios (parcialidad, mala fe, violencia, codicia...) a los representantes del poder real ${ }^{53}$.

Los estudios actuales no permiten determinar todavía como afectó exactamente toda esta dinámica a Girona que, según palabras de uno de sus síndicos a Cortes en 1450, era una de les insígnies e majors universitats del principat e contribuex en paguar e sorportar los càrrechs del dit principat en major porció que no soporta quasevol universitat del principat, exceptades les universitats de la ciutat de Barchinona e de la vila de Perpenya ${ }^{54}$. No obstante, y pese a la existencia del mitificado episodio del sitio de la Força gerundese en 1462, es de suponer que lo su-

\footnotetext{
52 SABATÉ CURULL, F., «Laugment de l'exigència fiscal en els municipis catalans al segle XIV: elements de pressió», en M. Sánchez y A. Furió (eds.), Corona, municipis i fiscalitat a la Baixa Edat Mitjana, Lleida, 1997, pp. 423-465. Una panorámica sobre la presión ejercida sobre los lugares de realengo en VERDÉS PIJUAN, P., «La Guerra Civil catalana i l'inici d'un nou cicle fiscal (Cervera, 1465-1516)», en Actes del Segon Congrés Recerques. Enfrontaments civils: postguerres i reconstruccions, vol. I, Lleida, 2002, pp. 128-144. Para los lugares de señorío: MORELLÓ, Fiscalitat i deute públic, pp. 200-209.

${ }^{53}$ Sin duda, para ilustrar esta cuestión no existe mejor ejemplo que las páginas que dedica C. Batlle a la tormentosa relación entre Galceran de Recasens y los consellers de la ciudad de Barcelona (BATLLE, La crisis social, vol. I, pp. 172-182). No obstante, para tener una visión más amplia del tema, he de remitirme de nuevo al discurso formulado por las autoridades de la villa de Cervera durante el s. XV, tal como se describe en el trabajo (todavía inédito en el momento de redactar este estudio) citado en la nota 48.

${ }^{54}$ JULIOL, Llibre Vermell, pp. 293-297.
} 
cedido en aquella ciudad fue similar a lo que se documenta en otros lugares del país, donde la negativa percepción de los oficiales reales acabó proyectándose también hacia la propia monarquía, contribuyendo al incremento de la tensión política que, finalmente, condujo hasta la Guerra Civil ${ }^{55}$. Como es sabido, tras la contienda civil, la resistencia municipal a las demandas reales disminuyó considerablemente ${ }^{56}$, para aumentar de nuevo posteriormente durante la época moderna y alcanzar su cenit en la antesala de la Guerra de Secesión (1640-1652), cuando la numantina resistencia de los regidores medievales ante el absolutismo real acabó de adquirir sus tintes míticos ${ }^{57}$.

\subsection{La fiscalidad municipal y la "contribución ciudadana»}

Que la comunitat pos alguns pochs càrrechs, e quaix insensibles al poble, a manera de imposicions o de generalitats en pa, en vi e.n totes coses. Ejamés no.ls fahesessen questes, ne fogatges ne coses que percebessen notablement, car aytals collectes agreugen molt to cor del poble, per bé que sia poch, e.l provoquen a ffer avalots, e rebel.lions e a mudar senyoria ${ }^{58}$. Este otro texto del Dotzè, puede servirnos para introducir la segunda gran cuestión que pretendo abordar en este trabajo, esto es, la creciente presencia de la fiscalidad municipal en la vida urbana y las consiguientes repercusiones que tuvo este hecho para la configuración del concepto de ciudadanía, la ordenación del espacio urbano y, en definitiva, la construcción de la identidad urbana.

A primera vista, las palabras del franciscano gerundense podrían parecer absolutamente contrarias a esta idea, puesto que se propugnaba tan sólo la existencia de una mínima fiscalidad (de carácter indirecto) y se renegaba del otro gran impuesto municipal en la época medieval, esto es, las derramas o tallas. Ahora bien, tal como sucedía en el caso de las demandas reales, debemos situar las palabras de Eiximenis en su preciso contexto, y lo primero que ha de advertirse es que el autor tampoco en este caso negaba la importancia de la fiscalidad local. Todo lo contrario: según el autor, tan sólo con las suficientes reservas de dinero, la comunidad podría hacer frente a sus muchas necesidades (provisions, deffensions, o obres o solemnitats o qualsevol altra cosa), defenderse de sus enemigos y escapar de cualquier peligro ${ }^{59}$. No obstante, Eiximenis apostaba claramente

\footnotetext{
55 Sobre el mito del sitio de la Força de Girona, en 1462, véase SOBREQUÉS VIDAL, S. y SOBREQUÉS CALLICÓ, J., La guerra civil catalana del segle XV, vol. 1, Barcelona, 1973, pp. $145-223$

${ }^{56}$ Véase por ejemplo, el trabajo ya citado de VERDÉS, «La Guerra Civil catalana», pp. 128-144.

${ }^{57}$ GRAU FERNÁNDEZ, R., "Joan Fiveller, Ferran I i les imposicions municipals de Barcelona. Repàs a un mite històric», en Barcelona. Quaderns d'Història, 2/3, Barcelona 1996, pp. 53-99.

${ }^{58}$ EIXIMENIS, Dotzè, I, 1, cap. 146.

${ }^{59}$ EIXIMENIS, Dotzè, I, 1, cap. 152, 193.
} 
por un determinado programa fiscal (y financiero) que, pese a no disponer de ningún capítulo concreto en el Dotzè, puede vislumbrarse perfectamente a lo largo de su obra.

Como he dicho, entre los dos recursos habituales del municipio, tallas e imposiciones, el franciscano se decantaba claramente por el impuesto indirecto y, sobre todo, por los derechos sobre el consumo de productos básicos. Esto es lo que puede deducirse de la cita con que se inicia el presente apartado, donde tan sólo se mencionan explícitamente los derechos sobre el pan y el vino, y del célebre capítulo donde se habla de la necesidad de promover el comercio, «vida de la cosa pública de la ciudad». Y es que la prosperidad de la comunidad (incluyendo la de su hacienda) se cimentaba, según el autor, sobre la actividad mercantil, razón por la cual debía evitarse la contraproducente tentación de solicitar a los mercaderes el pago de excesivos impuestos ${ }^{60}$.

Como veremos, las autoridades de Girona o, mejor dicho, un determinado sector del gobierno local compartían plenamente las tesis del franciscano, pero también aquí la propuesta fiscal del Dotzè ha de ser interpretada como el resultado del largo proceso de construcción del sistema financiero municipal así como de la progresiva aculturación fiscal experimentada por la población urbana en el principado. Una aculturación cuyo inicio puede documentarse ya, en algunos lugares del país, desde finales del s. XII y que, inicialmente, se desarrolló de forma exclusiva en el ámbito del denostado (por Eiximenis) impuesto directo, esto es, las collectas, tallas o comuns ${ }^{61}$.

En efecto, tal como se apuntaba en el apartado anterior, las primeras menciones a la universitas local en Cataluña van ligadas, en la mayoría de los casos, a la existencia de una caja común y/o a la recaudación de derramas para hacer frente a determinadas necesidades colectivas (tributos, obras, servicios...). Unas derramas que, desde mediados del s. XIII, son cada vez más frecuentes en las ciudades y villas catalanas, hasta el punto de convertirse prácticamente en ordinarias como consecuencia, sobre todo, de las periódicas demandas reales/señoriales en forma de questias y subsidios. En este contexto, la fiscalidad (directa) contribuye, junto a otros elementos concurrentes (defensa, urbanismo, arbitraje...), a la cris-

${ }^{60}$ EIXIMENIS, Regiment, cap. 21, 35, 36 ... La propuesta fiscal de Eiximenis acaba de tomar forma cuando propone la creación de lo que actualmente podríamos denominar bienes comunales, monopolios fiscales, tasas y estancos como alternativa para conseguir dinero, lo cual a la postre no es otra cosa que una forma encubierta de fiscalidad indirecta sobre el consumo (EIXIMENIS, Dotzè, I, 1, cap. 146).

${ }^{61}$ El ejemplo más precoz de la recaudación de derramas comunitarias en Cataluña corresponde a Lleida, tal como nos muestra TURULL RUBINAT, M., «El naixement de la fiscalitat municipal a Lleida (1149-1289)», en M. Sánchez y A. Furió (eds.), Corona, Municipis i Fiscalitat a la Baixa Edat Mitjana, Lleida, 1997, pp. 219-232. 
talización institucional del Consell que, según algunos autores, desde sus orígenes es el titular de una «jurisdicción tributaria autónoma» ${ }^{62}$. Sin entrar a valorar esta afirmación ni tampoco las disquisiciones jurídicas al respecto ${ }^{63}$, lo cierto es que las derramas se convirtieron muy pronto en un elemento central de la vida comunitaria y clara prueba de ello son las tempranas pugnas sociales vividas en torno al repartimiento de las tallas. Fruto de estos conflictos, durante la segunda mitad del s. XIII, el criterio de repartición proporcional, también conocido como talla «per sou e per lliura», se establece progresivamente por doquier y, como consecuencia lógica de este hecho, aparece un verdadero símbolo fiscal: los padrones de riqueza, conocidos en el principado como estimes, valies o manifests ${ }^{64}$.

Aunque los inventarios del s. XV no mencionen la existencia de otro arcón lleno de estimes, valies o manifests, cabe suponer que este tipo de fuentes fiscales también debieron existir en Girona y, no sólo eso, sino que constituyeron un elemento trascendental para la definición de la identidad urbana de la población ${ }^{65}$. Recordemos una vez más que estos registros eran resultado del progresivo establecimiento, durante el s. XIII, del impuesto proporcional (per sou e per lliura) que, en el caso de Girona, aparece sancionado definitivamente por el rey en el privilegio fundacional del año 1284, donde también se regulan

62 Véase, por ejemplo, el texto de las costumbres de Tortosa (1272/1277), estudiadas por MONTAGUT ESTRAGÚES, T. de, «La doctrina medieval sobre el munus y los comuns de Tortosa», en Homenaje in memoriam Carlos Díaz Rementería, Salamanca, 1998, pp. 475-489.

${ }^{63}$ TURULL RUBINAT, M., «Arca communis: dret, municipi i fiscalitat (D’una petició de privilegi fiscal al s. XVIII als orígens medievals de la fiscalitat municipal a Catalunya), en Initium. Revista Catalana d'Història del Dret, 1, Barcelona 1996, pp. 581-610.

${ }^{64}$ Como he apuntado, Lleida es la primera ciudad catalana donde se documentan polémicas, a finales del s. XII y principios del XIII, a propósito de la contribución proporcional de los bienes de los vecinos en las derramas comunitarias (TURULL, «El naixement de la fiscalitat», pp. 219-232). Posteriormente, el año 1226, para acabar con las discordias que provocaba el pago de tallas en la ciudad de Barcelona, Jaime I disponía que estas deberían pagarse per solidum et libram, expresión que se repetiría a menudo para designar este tipo de contribución (ORTí, «El Consell de Cent», pp. 33-34). Aunque no siempre aparezca la expresión concreta per sou e per lliura, la utilización de este criterio de proporcionalidad también puede inferirse de los conflictos y/o la promulgación de disposiciones al respecto en Perpinyà (1263), Puigcerdà (1269), Cervera (1272), Tortosa (1272/1279), Tarragona (1272-1289), Montblanc (1283)... Cf. FONT RIUS, J.M., «La administración financiera en los municipios medievales catalanes», en Historia de la Hacienda española (épocas antigua y medieval). Homenaje al Prof. García de Valdeavellano, Madrid, 1982, pp. 213-215; TURULL, La configuració jurídica, p. 493; MONTAGUT, «La doctrina medieval», pp. 482; RECASENS i COMES, J.M., La ciutat de Tarragona, vol. II, Barcelona, 1975, pp. 175-177.

${ }^{65}$ Véanse las referencias a los restos de la documentación fiscal (incluidas estimes) conservada en Girona para la fiscalidad directa municipal en GUILLERÉ, Ch., «Les sources financières et fiscales a Gérone à la fin du Moyen Âge», en D. Menjot y M. Sánchez (coord.), La fiscalité des villes au Moyen Âge (France méridionale, Catalogne et Castille). 1. Étude des sources, Toulouse, 1996, pp. 45-56. 
otras cuestiones relacionadas con la recaudación de tallas para hacer frente tanto a los «servicios reales» como a los «vecinales» ${ }^{66}$. Se deduce, por tanto, que en aquellos momentos ya existía algún tipo de padrón de riqueza, por simple que fuera, y que su características fueron evolucionando -tal como sucedió en otros lugares- al ritmo de las disposiciones reales y, sobre todo, de los acuerdos tomados por el Consell ${ }^{67}$.

Como es sabido, en principio, estos padrones de riqueza contenían las declaraciones de bienes muebles e inmuebles realizadas por todos los vecinos o ciudadanos que, por el mero hecho de serlo, estaban obligados a contribuir $^{68}$. En este sentido, incluso aquellas personas pobres que apenas disponían de propiedades aparecían nominalmente en las estimes (ponían acompañados de la expresión nichil), aunque luego muchas veces no pagaran nada en las derramas o su contribución fuera mínima ${ }^{69}$. También cabe destacar que todos los declarantes aparecían ubicados dentro de una determinada circunscripción fiscal (quarters, barrios, calles...), cuyo conjunto conformaba una particular topografía urbana que, seguramente, el impuesto directo

${ }^{66}$ GUILLERÉ, Llibre Verd, pp. 46-49.

${ }^{67}$ No recordaré los numerosos privilegios y disposiciones reales que pueden hallarse en los pergaminos, libros de privilegios y correspondencia de Girona, remitiéndome tan sólo a la síntesis general sobre los padrones de riqueza en el principado realizada por TuRuLL RUBINAT, M. y MORELLÓ BAGET, J., «Estructura y tipología de las estimes-manifests en Catalunya (siglos XIV-XV)», en Anuario de Estudios Medievales, 35/1, Barcelona, 2005, pp. 271-326.

${ }^{68}$ En este sentido, resultan muy interesantes las reflexiones de Ph. Daileader cuando afirma que «le roi Jacques Ier d'Aragon qualifiait Perpignan de communauté pas moins de quatre fois les 30 août 1274», y que «à cette date il réunit entre eux les éléments constitutifs de cette communauté, qui avaient existé indépendamment l'un de l'autre. Ces éléments étaient au nombre de deux: l'obligation mutuelle de paiement des taxes et la citoyenneté. Antériurement à 1274, le non-paiment des impôts communaux n'excluait personne de la citoyenneté. Maintenant c'était le cas» (DAILEADER, De vrais citoyens, pp. 27-48, esp. 27). Véanse también los elocuentes datos al respecto, que aparecen en las Costumbres de Tortosa (1272/1277): MONTAGUT, «La doctrina medieval», pp. 483-489.

${ }^{69}$ En las Costumbres de Tortosa (1272/1277), por ejemplo, se establecía que la gent pobre deuen pagar segons que.ls ciutadans ordenen o volen ordenar sens tot contrast... axí però que.s face ab raó (MONTAGUT, «La doctrina medieval», p. 488). A principios del s. XIV, en Barcelona, se seguía un criterio similar, que también fue adoptado por los regidores de la ciudad de Manresa el año 1312 (TORRAS i SERRA, M., «El sistema de redacció dels manifests a Barcelona i Manresa a inicis del s. XIV», en Acta Historica et Archaeologica Medievalia, 22/2, Barcelona 2001, pp. 347-348). Y, finalmente, cabe recordar el caso de Cervera el año 1377, donde las autoridades locales acordaban quant és dels singulars que no han renda ne moble, són persones qui deuen e poden de alguna cosa ajudar a la universitat... que és rahó que tothom ajut als càrrechs de la vila a pagar (TURULL, La configuració del municipi, p. 498). 
contribuyó a consolidar ${ }^{70}$. Y, en el caso de los varones mayores de edad, tampoco puede olvidarse que la cuantía de la riqueza declarada servía -entre otras cosas- para situarles dentro de una determinada categoría socioeconómica o mà, elemento fundamental en la mayoría de ciudades y villas del principado para regular el acceso al gobierno local ${ }^{71}$.

Resulta evidente, por consiguiente, que la contribución al impuesto directo municipal -materializada básicamente en las estimes- constituía un elemento importante a la hora de definir la identidad urbana en el principado desde el s. XIII, como también lo era -aunque fuera a contrario- la exención fiscal y los frecuentes conflictos que esta planteaba. Si, como decía, todos los vecinos o ciudadanos aparecían en los padrones o estimes por el simple hecho de serlo, la ausencia en dichos registros de determinados individuos o grupos sociales, residentes o propietarios en la ciudad, también respondía a su exclusión de la universitas local ${ }^{72}$. Aunque las razones de la exención diferían según el caso, tanto nobles como eclesiásticos, judíos, musulmanes, transeúntes y «forasteros»-en principio- no estaban obligados a declarar sus bienes ni a contribuir por ellos, entre otras cosas, porque no eran considerados vecinos o ciudadanos ${ }^{73}$.

${ }^{70}$ Recuérdese, por ejemplo, el clásico trabajo sobre Girona de GUILLERÉ, Ch., «Aspects de la société géronaise a la fin du XIVème siécle. Approches topographique et professionnelle a travers le registre de taille de 1388», en Annals de l'Institut d'Estudis Gironins. Homenatge a Lluís Batlle i Prats, 25/1, Girona, 1979-1980.

${ }^{71}$ Sin duda, el ejemplo más ilustrativo sobre esta cuestión nos lo ofrece J. Morelló para los casos de Reus y Valls: MORELLÓ, Fiscalitat i deute públic, pp. 351-352, 371-374. De todas formas, también cabe mencionar los matices que introduce a la visión puramente fiscal de dichas categorías Ch. Guilleré, precisamente, para el caso de Girona: GUILLERÉ, Ch. (1993), Girona al segle XIV, vol. 2, Barcelona, 1993, pp. 254-265.

${ }^{72}$ En este sentido, especialmente ilustrativo resulta el caso de los nobles: por regla general, este grupo social se resistió a la contribución, amparándose en su condición privilegiada, y la reacción municipal ante esta actitud fue la negación de los derechos de ciudadanía a los nobles, así como del consiguiente acceso a la institución de gobierno municipal FERRO, V., El Dret Públic Català. Les Institucions a Catalunya fins al Decret de Nova Planta, Vic, 1987, pp. 151-152 y 325-330. Un interesante ejemplo de este hecho lo hallamos en el texto de una carta enviada el año 1332 por los consellers de Barcelona a los jurats de Girona, explicándoles que los nobles residentes en la ciudad no debían contribuir porque no eran considerados ciudadanos ni participaban en el Consell (GUILLERÉ, Girona al s. XIV, p. 244).

${ }^{73}$ Otra cosa distinta es que, en ocasiones, estos colectivos acaben apareciendo en los padrones porque el carácter real del impuesto directo así lo justificaba, es decir, porque poseían bienes que habían pertenecido anteriormente a contribuyentes y, por tanto, estaban obligados a las deudas contraídas por la comunidad. Tampoco debe confundirnos la contribución puntual de dichos colectivos por razón de los beneficios obtenidos por sus propiedades gracias a la acción municipal, por ejemplo, la protección de las murallas. Sobre esta cuestión y los conflictos que provocó en el principado, véase: MORELLÓ BAGET, J., «Les resistances à l'impôt dans les municipalités catalanes (du XIIIe au XIV e siècle): tentative de synthèse», 
Finalmente, para concluir con la interpretación que puede hacerse de este símbolo fiscal, cabe destacar la trascendencia que también tuvo, para la aculturación fiscal de la población, el procedimiento utilizado para la confección de los padrones (así como el virtual y la retórica que lo acompañaban). En efecto, después de los conflictos iniciales que siguieron a la implantación del impuesto directo municipal, se documentan repetidas disposiciones reales/señoriales y acuerdos municipales para que la declaración y estimación de los bienes se hiciera de la forma lo más correcta y justa posible. Para ello, se dispuso que todo el mundo declarara y evaluara sus propiedades bajo juramento, se nombraron comisiones de prohombres «honrados, expertos y dignos de fe» para revisar estas declaraciones, se arbitraron los mecanismos necesarios para que las estimes pudieran ser revisadas periódicamente y con el propósito de acabar con cualquier sombra de duda, en algunos lugares, incluso se documenta la práctica de exponer públicamente los padrones en la casa consistorial ${ }^{74}$. Todo ello, sin embargo, no nos debe hacer perder nunca de vista que las tallas realizadas a partir de las estimes debían respetar hacer una cierta «lógica» regresiva (apuntada, también, por Eiximenis) ni que la causa impositionis de la exacción podía alterar -siempre que fuera de forma extraordinaria, moderada y debidamente justificada- la habitual proporcionalidad ${ }^{75}$.

Evidentemente, de lo expuesto hasta el momento no debe inferirse que las tallas dejaran de provocar conflictos por una u otra razón en Cataluña, pero sí puede afirmarse que, a mediados del s. XIV, tanto su establecimiento como su recaudación habían generado un notable consenso social ${ }^{76}$. Fue entonces cuando, en algunos casos, apareció y, en otros, se consolidó un nuevo recurso fiscal: me refiero a las sises, ajudes o imposicions. Como es sabido, estas eran las distintas denominaciones con que se conocía el impuesto indirecto sobre el

en D. menjot, A. Rigaudière y M. Sánchez (dir.), Limpôt dans les villes de l'Occident méditerranéen (XIIIe-XVe siècle), Paris, 2005, pp. 400-410.

${ }^{74}$ Véanse los innumerables datos que proporciona al respecto la síntesis de TURULL y MORELLO, «Estructura y tipología», esp. 284-295.

75 Sobre la «lógica» regresiva de las derramas en Cataluña, resulta especialmente ilustrativo un documentos de 1312, que regulaba la forma de los padrones de riqueza en la ciudad de Manresa (a imagen de Barcelona), donde se establecía que debía tenerse ...sguart a la taxatió dels mylors per so con fan gran messió e no saben guanyar con que despenen ço que han e encara que tenen la ciutat honrada e defesa e mantenguda e són continuament en Conseyl... (TORRAS, «El sistema de redacció», p. 348). Por lo que respecta a la interesante cuestión de la causa impositionis, me remito nuevamente al estudio sobre las Costumbres de Tortosa de MONTAGUT, «La doctrina medieval», pp. 486-489.

${ }^{76}$ Sobre los diferentes tipos de conflicto que continuaron generando las tallas así como las controversias provocadas por los intentos de establecer impuestos sobre la renta, véase MORELLÓ, «Les resistances à l'impôt», pp. 400-412, 418-426. 
consumo de productos básicos y el comercio de mercancías que, desde finales del s. XIII, había empezado a percibirse en las ciudades y villas del principado para hacer frente a algunas demandas reales/señoriales o a determinadas necesidades de la comunidad (por ejemplo, la fortificación urbana). Inicialmente, este recurso tan sólo se establecía de forma extraordinaria, previa autorización real o señorial, pero a medida que avanza el s. XIV las imposicions cobraron cada vez mayor protagonismo como consecuencia de las posibilidades que ofrecía su arrendamiento para hacer frente al incremento de la presión fiscal de la Corona, a las crecientes necesidades comunitarias y al consiguiente endeudamiento municipal. Especialmente importante fue la implantación del nuevo impuesto en los lugares del realengo después de 1350, sobre todo y en las ciudades o villas de mayor entidad ${ }^{77}$.

Girona pertenecía a este último grupo de poblaciones reales, cuya entidad demográfica y actividad comercial permitieron que las imposicions se consolidasen definitivamente durante la segunda mitad del s. XIV. Recaudado como mínimo desde 1331, el impuesto indirecto se convirtió de facto en ordinario gracias a la asignación de su producto a la financiación de la deuda a largo plazo que, como hemos visto, había devenido prácticamente irredimible. Pero eso no fue todo: las múltiples (y objetivas) ventajas que, como expediente financiero, ofrecía el arriendo de las imposicions al mejor postor también acabaron convirtiendo esta nueva exacción en el principal recurso municipal y ello en claro detrimento de las tallas. Como puede suponerse, la inevitable complejidad administrativa que requería la confección de los padrones y la percepción de las derramas proporcionales sobre la riqueza así como la congénita aversión que tradicionalmente ha despertado el impuesto directo contribuyeron, también en este caso, al progresivo retroceso de las derramas, que acabaron siendo fuente de financiación secundaria tanto en Girona como en otras grandes ciudades y villas del principado ${ }^{78}$.

\footnotetext{
${ }^{77}$ Para el caso de Girona, véase GUILLERÉ, Ch., «Un exemple de fiscalité urbaine indirecte: les imposicions géronaises aux XIVe e XVe siècles», en D. Menjot y M. Sánchez (coord.), La fiscalité des villes au Moyen Âge (Occident méditerranéen). 2. Les systemes fiscaux, Toulouse, 1999, pp. 423-445. Para una perspectiva más general: ORTí GOST, P., SÁNCHEZ MARTÍNEZ, M. y TURULL RUBINAT, M., «La génesis de la fiscalidad municipal en Cataluña», en Revista d'Història Medieval, 7, Valencia 1996, pp. 115-134.

${ }^{78}$ Respecto al caso de Girona, remito de nuevo a GUILLERÉ, «Un exemple de fiscalité», pp. 399-422. Por supuesto, también resulta paradigmático el ejemplo de Barcelona: ORTI GOST, P. «Les imposicions municipales catalanes au XIVe siècle», en D. Menjot y M. Sánchez (coord.), La fiscalité des villes au Moyen Âge (Occident méditerranéen). 2. Les systemes fiscaux, Toulouse, 1999, pp.399-422. Y, finalmente, cabe mencionar asimismo el caso de una población de señorío como Castelló d’Empúries: SÁNCHEZ, «Fiscalidad y finanzas», pp. 301-362.
} 
Llegados a este punto, ya podemos imaginar porqué, a finales del s. XV, no aparece ningún arcón repleto de padrones en los inventarios del archivo municipal gerundense. Y es que, desde mediados del s. XIV, las imposicions tomaron progresivamente el relevo de las tallas en todos los sentidos, incluido el proceso de configuración de la identidad urbana. No en vano, prácticamente desde que el impuesto diera sus primeros pasos, las autoridades municipales habían tenido que luchar continuamente contra todos aquellos que, de una u otra forma, cuestionaban su potestad para recaudar el tributo, perjudicando tanto sus intereses económicos como -según ellos- la «cosa pública» de la ciudad. Primero, habían sido los miembros de los brazos nobiliario y eclesiástico quienes, en el marco de las Cortes, reclamaron insistentemente la abolición del nuevo impuesto indirecto municipal, provocando asimismo numerosos conflictos cuando, aquí o allá, negaban la obligación de sus vasallos a satisfacer los derechos en el mercado de la ciudad ${ }^{79}$. Luego habían sido los regidores de otros lugares, especialmente de aquellos donde todavía no se pagaba el impuesto (o sus tarifas eran insignificantes), o bien la simple imposibilidad de controlar el espacio comercial lo que había puesto en peligro la continuidad del tributo ${ }^{80}$. Y, finalmente, el municipio había tenido que hacer frente también a la propia monarquía que, ávida de recursos, hizo todo lo posible para adueñarse y/o recuperar el control de tan suculento recurso fiscal ${ }^{81}$.

No ha de extrañarnos, por tanto, que los jurados de Girona (al igual que los de muchas otras poblaciones) conservaran con tanto interés -junto a otras libertades teóricamente más trascendentales- todas las autorizaciones puntuales, los capítulos generales de Cortes e incluso los contratos de censales que, combinados, garantizaban su derecho a imponer las sisas. Ni tampoco ha de sorprendernos la vehemencia con que los regidores resistieron a los repetidos intentos de la Corona de poner en cuestión tanto la jurisdicción municipal como la autonomía financiera del municipio en este ámbito fiscal ${ }^{82}$. Como decía en el apartado an-

79 VERDÉS PIJUAN, P., «A propòsit del privilegi general per recaptar imposicions atorgat per Pere el Cerimoniós (1363)», en Miscelllània de Textos Medievals, 8, Barcelona 1996, pp. 231-248.

${ }^{80}$ Especialmente ilustrativo resulta, también en este caso, el ejemplo de Girona: CASTELLS i CALZADA, N., «El districte de la mitja llegua entorn les muralles de la ciutat de Girona», Annals de l'Institut d'Estudis Gironins, 28, Girona 1985-1986, pp. 299-325.

${ }^{81}$ TURULL RUBINAT, M. i VERDÉS PIJUAN, P., «Sobre la hisenda municipal a Constitucions y altres drets de Cathalunya (1704)», en M. Sánchez. (ed.), Fiscalidad real y finanzas urbanas en la Cataluña Medieval, Barcelona, 1999, pp. 121-154, esp. 126-140; VERDÉS PIJUAN, P., «Sobre la regalia d'establir imposicions i barres a Catalunya: la convinença de Sant Joan Despí (1370)», en Initium. Revista Catalana d'Història del Dret, 10, Barcelona 2005, pp. 545578, esp. pp. 545-549. Véase también toda la bibliografía que se cita en este último estudio. 82 Vid. nota supra. 
terior, esta y otras injerencias reales fueron consideradas como una importante «deslibertad» para la ciudad, máxime cuando -y así se manifestaba en las Cortes de Monzón de 1470- las imposiciones són la ànima de les ciutats, vilas e lochs en lo dit principat de Cathalunya ne sens aquellas se puga suplir als càrrecs, las quals ab privilegis los poblats en lo dit principal de Cathalunya dels gloriosos reys de inmortal memoria... han hagut e obtés ${ }^{83}$.

Una prueba más de este hecho es también la tremenda influencia que acabaron ejerciendo dichos impuestos -recordémoslo, sobre el consumo de productos básicos y el comercio de mercancías- tanto en el espacio urbano como en la vida cotidiana de los habitantes de la ciudad. Aunque la fiscalidad indirecta tradicional, de raíz señorial (lezdas, peajes, portazgos...), ya había tenido una importante repercusión en este sentido, mucho mayor fue la de las imposicions. Los procedimientos ideados para cobrar estos impuestos municipales se superponían a las antiguas infraestructuras fiscales del señor, en muchos casos obsoletas, e incrementaban notablemente el control fiscal sobre la población. Desde mediados del s. XIV (o incluso antes), son diversos los ámbitos donde pueden apreciarse los efectos de la política fiscal del municipio: centralización de espacios comerciales (calles, plazas, mercados...), apropiación de monopolios y servicios señoriales (carnicerías, pescaderías, pesos y medidas...), control de los intermediarios (corredores, notarios, revendedores)... ${ }^{84}$. A ello se sumaba la creación de nuevos edificios municipales, como las «casas del peso», por donde debía pasar toda la harina llevada por los vecinos a los molinos u otros productos; el establecimiento de complejos mecanismos (casi «rituales fiscales») para controlar, por ejemplo, la venta de vino al detalle en las tabernas; o la existencia de un claro precedente del impuesto sobre el valor añadido, que los distintos comerciantes tenían la obligación de declarar y pagar periódicamente ${ }^{85}$. Aunque, sin duda, la máxima expresión de toda esta política fiscal fue la aparición durante el s. XV, en algunos lugares, de un sofisticado procedimiento de recaudación

${ }^{83}$ TURULL i VERDÉS, «Sobre la hisenda municipal», p. 132, n. 29.

${ }^{84}$ GUILLERÉ, «Un exemple de fiscalité», pp. 423-445; ORTI «Les imposicions municipales», pp. 399- 422; VERDÉS PIJUAN, P., «La gestión de los impuestos indirectos municipales en las ciudades y villas de Cataluña: el caso de Cervera (s. XIV-XV)», en D. Menjot y M. Sánchez (coord.), La fiscalité des villes au Moyen Âge (Occident méditerranéen). La gestion de l’impôt, Toulouse, 2004, pp. 173-189; MORELLÓ, Fiscalitat i deute públic, pp. 485-544 (esp. 539-544).

${ }^{85}$ Además de los datos ofrecidos sobre estas cuestiones por los trabajos citados en la nota anterior, también merecen ser citadas por su detalle dos obras que se ocupan concretamente de todo el procedimiento utilizado para cobrar los impuestos sobre el vino: SÁNCHEZ MARTÍNEZ, M., «Sobre la viña y el vino en las ordinacions municipales de la Cataluña medieval», en La vita e il vino. Storia e diritto (secoli XI-XIX), vol. 1, Roma, 2000, pp. 109-147; SABATÉ CURULL, F., «El ban del vi a Puigcerdà a la segona meitat del segle XIV», en III Col.loqui d'Història Agrària. Vinyes i vins: mil anys d'història, Barcelona, 1993, pp. 299-315. 
integrada y centralizada, el butlletí, cuyo objetivo era optimizar el rendimiento de las imposicions, regulando incluso los horarios comerciales de la ciudad ${ }^{86}$. No sabemos todavía si Girona estableció también el butlletí, pero lo que sí resulta evidente -a la luz de los inventarios de la casa consistorial y de otros documentos conservados- es el interés que tenían los jurats, desde mediados del s. XIV, en controlar tanto los pesos y medidas utilizados en la ciudad como, en general, la actividad comercial ${ }^{87}$.

Por último, lo que sí puede documentarse perfectamente en Girona son los conflictos provocados, a distintos niveles, por el incremento progresivo de la presión fiscal de las autoridades municipales, así como el interesante discurso utilizado para justificar (o criticar) una determinada estrategia impositiva. Como puede suponerse, artesanos, mercaderes y comerciantes en general no siempre aceptaron de buen grado las distintas iniciativas municipales en este ámbito, sobre todo cuando percibían que se les estaba cargando con una doble imposición (al comprar las materias primas y vender los productos manufacturados) o, simplemente, cuando consideraban que el impuesto local minaba su competitividad. Asimismo, tampoco estuvieron exentos de polémica los reiterados intentos de extender la fiscalidad indirecta municipal a los individuos o grupos tradicionalmente exentos que residían en la ciudad (o pasaban por ella), siendo especialmente importantes los enfrentamientos protagonizados por las autoridades locales y el clero, la nobleza, los judíos o incluso la monarquía ${ }^{88}$. Y, finalmente, no puedo acabar sin referirme también a la creciente tensión documentada, desde finales del s. XIV, entre los sectores más desfavorecidos de la universidad (o, dicho en otras palabras, el poble menut) por el descarado incremento de los impuestos sobre el consumo de productos básicos.

Como ya he mostrado en otro trabajo, todas estas controversias dieron lugar a una elaborada retórica presidida por los habituales lugares comunes del discurso político de la época, que oscilaba entre el omnipresente ideal de justicia

${ }^{86}$ Conocemos perfectamente este sofisticado (para la época) procedimiento, documentado como mínimo en Barcelona, Vic, Manresa y Cervera, gracias a las ordenanzas que mandaron realizar las autoridades de este último lugar, en 1460, a imagen de las que existían en otras poblaciones: VERDÉS PIJUAN, P., «La levée de l'impôt indirect dans les municipalités catalanes: Les ordonnances du butlletí de Cervera (1460)», en D. Menjot y M. Sánchez (coord.), La fiscalité des villes au Moyen Âge (Occident méditerranéen). 2. Les systèmes fiscaux, Toulouse, 1999, pp. 447- 462.

${ }^{87}$ BATLLE, «Pesos, mides i mesures» pp. 103-107; CASTELLS, «El districte de la mitja llegua», pp. 299-325; GUILLERÉ, Girona al s. XIV, pp. 164-165; FERNÁNDEZ, Una familia catalana, p. 92.

${ }^{88}$ Nuevamente, remito a la síntesis realizada por MORELLÓ, «Les resistances à l'impôt», pp. 412-418. 
y el interés general de la comunidad ${ }^{89}$. Un discurso que entronca directamente con los planteamientos de F. Eximienis, los cuales no diferían sustancialmente de los que documentamos en una interesante carta dirigida por el rey Juan I a los regidores de Girona, pocas semanas después del avalot de 1391 contra los judíos. En esta misiva se reprochaba al «partido popular» que pretendiera acabar con las imposicions y sustituirlas por una derrama (talla) proporcional per sou e per lliura a la riqueza de los contribuyentes. Según el monarca, además de ilegal, tal pretensión era totalmente ilógica, puesto que el establecimiento del impuesto directo no bastaría ni mucho menos para financiar la deuda municipal sino era a costa de despoblar la ciudad; todo lo contrario que las imposicions, que proporcionaban un mayor rendimiento que las tallas, repercutiendo además, en gran parte, sobre los forasteros que pasaban por Girona ${ }^{90}$. Tales palabras, además de mostrarnos a qué intereses concretos servía Eiximenis, nos revelan la existencia de una enconada pugna fiscal en la ciudad, que se prolongaría durante el s. XV, y también nos dejan entrever la importante cultura y conciencia colectiva que, en el ámbito fiscal, habían acabado adquiriendo los gerundenses a finales de la época medieval ${ }^{11}$.

\subsection{LA ADMINISTRACIÓN FINANCIERA Y EL «BUEN GOBIERNO» DE LA CIUDAD}

Que en lo despendre sia tothom attès e diligent que hun diner petit no se.n despena sinó en lochs públicament necessaris e inexcusables, e qui solament toquen lo profit de la comunitat. E que officis supèrfluus e salaris desmesurats sien diminuits e portats a regle, e que tota despesa de comú sàpia tota la comunitat. E que no sien regidors hòmens pobres, ne diffamats, ne mercaders, ne qui mal hagen administrat to seu, màs hòmens de honor, e de consciència e de vergonya, qui hagen fama de gran

\footnotetext{
${ }^{89}$ Vid. nota 48.

${ }^{90}$ Debido a su extensión, no transcribo el texto original, que puede hallarse en GUILLERÉ, «Un exemple de fiscalité», p. 442. Sí que recordaré, sin embargo, los conflictos y argumentos similares que se documentan en Valls (1369), Cervera (1384), Barcelona (1391), Lleida, $(1388,1402,1413)$ o Tarragona $(1422,1447)$ : MORELLÓ, «Les resistances à l'impôt», pp. 410-411; BATLLE, La crisis social, vol. I, pp. 111-122; FERRER MALLOL, M.T., «Un memorial de greuges de la mà menor de Lleida contra la mà major (s. XV)», en Miscel.lània Homenatge a Josep Lladonosa, Lleida, 1992, pp. 293-314 (esp. 309-313); CORTIELLA ÒDENA, F., Una ciutat catalana a darreries de la baixa edat mitjana: Tarragona, Tarragona, 1984, pp. 175, 185.

${ }^{91}$ En el caso de Girona, documentamos otras dos referencias al carácter pernicioso de las tallas que los menuts pretendían establecer en 1452 y 1457 (BATLLE, La crisis social, vol. I, p. 218; SOBREQUÉS i VIDAL, S., Societat i estructura política de la Girona medieval, Barcelona, 1975 pp. 111-112).
} 
zel de la comunitat ${ }^{92}$. Esta es tan sólo una de las numerosas referencias contenidas en el Dotzè, según las cuales el dinero público debía ser gestionado correctamente y por personas idóneas, si quería garantizarse la prosperidad general de la comunidad.

Nos encontramos, por tanto, ante la tercera y última cuestión que pretendía abordar en el presente estudio, esto es, la progresiva trascendencia adquirida en el principado por la administración financiera dentro del ejercicio del «buen (y mal) gobierno» de la ciudad. Como hemos visto, tras poner coto a la voracidad del monarca, el franciscano apostaba claramente por un determinado programa fiscal (y financiero), que proporcionara a las autoridades locales todos los recursos necesarios para hacer frente a las necesidades comunes. Ahora bien, según Eiximenis, de nada serviría todo esto si, paralelamente, no se acompañaba de una «administración leal» de los recursos municipales, de una gestión diligente y de un gasto moderado, especialmente por lo que a los salarios y retribuciones se refiere ${ }^{93}$.

Cualquier actuación contraria a estos principios era totalmente inadmisible y constituía el peor de los pecados, puesto que dañaba gravemente al conjunto de la comunidad y, además, atentaba contra la integridad de los menos afortunados, que eran los que acababan pagando más tributos. ${ }^{94}$. Como he dicho, el autor del Dotzè, también apostaba por el gobierno de unos pocos individuos suficientemente ricos, aptos y bien considerados, quienes debían, no obstante, contar siempre con la opinión de un consejo amplio en las cuestiones más trascendentales. Por el contrario, Eiximenis advertía repetidamente contra los regidores pobres (presa fácil de la corrupción), negligentes y sin la necesaria reputación, alertando también de los peligros que habitualmente entrañaba la «multitud» para la cosa pública ${ }^{95}$.

Siguiendo el planteamiento de los anteriores apartados, de nuevo tengo que empezar insistiendo en la necesidad de situar los textos del Dotzè así como los valores que estos atribuyen a la ciudad catalana medieval en su preciso contexto histórico y al servicio de unos intereses políticos muy concretos. Probablemente, las palabras del franciscano no tendrían mucho sentido durante el s. XIII, cuando tan sólo se prefiguraba la existencia de una bolsa común que, como hemos visto, era el producto de la recaudación más o menos regular de tallas y estaba

${ }^{92}$ EIXIMENIS, Dotzè, I, 1, cap. 146. Otra elocuente expresión en el mismo sentido: Nosaltres no volem tal profit qui.ns dapne les ànimes e per lo qual hajam a ésser ladres de la comunitat, ne volem guany qui.ns procur a la fi pèrdua de tot quant havem, mas desijam profit de la comunitat estojant-li tot ço que podem en guisa que un diner no.n vaja a mal (EIXIMENIS, Dotzè, I, 1, cap. 55).

${ }^{93}$ EIXIMENIS, Dotzè, I, 1, cap. 60, 61, 195.

${ }^{94}$ EIXIMENIS, Dotzè, I, 1, cap. 55, 57, 58.

95 Ibídem, cap. 58-68; EIXIMENIS, Regiment, cap. 1-39. 
regida por unos difusos representantes de la recién constituida universidad. Sin embargo, a medida que avanza el s. XIV, las crecientes demandas reales/señoriales, las perentorias necesidades comunitarias y el consiguiente endeudamiento exigieron, como también veíamos, la puesta en marcha de un complejo sistema fiscal y financiero. Fruto de esta dinámica, la administración de la hacienda local fue complicándose progresivamente, hasta convertirse en una materia política sensible a causa de las frecuentes dificultades económicas de los consistorios y de la elevada presión fiscal. Dicho en otras palabras, las recomendaciones de Eiximenis adquieren su pleno sentido a finales del s. XIV, cuando aumentan las acusaciones de negligencia y/o corrupción formuladas contra las oligarquías locales y la gestión financiera acaba por convertirse en una arma arrojadiza en las luchas por el gobierno municipal.

En el caso de Girona, el tema todavía no ha sido lo suficientemente estudiado y, probablemente, las fuentes municipales tampoco ayudan a ello, puesto que los jurats siempre procuraron silenciar a sus opositores ${ }^{96}$. De todas formas, existen numerosos indicios que también apuntan a la existencia de una dinámica similar a que se acaba de describir. Después del privilegio fundacional de 1284, donde las finanzas municipales ya ocupaban un lugar de primer orden, fue durante la primera mitad del trescientos cuando el erario se consolidó definitivamente como uno de los principales símbolos del gobierno local ${ }^{97}$. Especialmente ilustrativo resulta el texto de una disposición real de 1341, en virtud la cual se ratificaba el nombramiento de los jurados de aquel año (realizado, todavía, en el convento de los franciscanos), ordenándose a sus antecesores que les entregasen tecam comunem, sigillum, privilegia dicte civitatis et aliaque per iuratos dicte civitatis debent teneri et regi ${ }^{98}$. No sabemos si los conflictos que se producen en la ciudad entre 1320 y 1340 , provocados todos ellos por las aspiraciones políticas de los populares (mano menor) ${ }^{99}$, tuvieron algo que ver con

${ }^{96}$ El año 1324, por ejemplo, intuimos el conflicto gracias a una disposición municipal, según la cual no se podían recaudar ninguna talla que no hubiese sido decidida por el consell reunido mediante pregonero, jurats y consellers de la ciudad conjuntamente, y ningún mensajero tampoco podría ser enviado al rey, al infante o a cualquier otra persona si esto no había sido decidido asimismo por dicho consejo (GUILLERÉ, Llibre Verd, pp. 138-139).

${ }^{97}$ Recordemos una vez más que en esta disposición, además del nombramiento anual de los futuros jurats, ya se establecía la designación de auditores de cuentas para fiscalizar la recaudación de las tallas (GUILLERÉ, Llibre Verd, pp. 46-49).

${ }^{98}$ ARNALL, Lletres reials, vol. I, pp. 339-340.

99 Sobre los conflictos políticos que se producen en Girona durante esta época, véase: GUILlERÉ, Ch., «Politique et société: les jurats de Gérone (1323-1376)», en E. Sáez, C. Segura y M. Cantera, La ciudad hispánica durante los siglos XIII al XVI, 3 vol., Madrid, 1985, pp. 1443-1463; GUILLERÉ, Girona al s. XIV, vol. I, pp. 147-170; vol. II, pp. 247-308; FERNÁNDEZ, Una familia catalana, pp. 91-100. 
la manifiesta importancia adquirida por el arca común, pero resulta muy sintomático que el incremento de la tensión política coincidan precisamente con el aumento de las demandas reales y el consiguiente ascenso de la presión fiscal sobre la población urbana ${ }^{100}$.

Algo similar podría pensarse de las disputas documentadas con posterioridad a dicha fecha, y hasta finales del s. XIV ${ }^{101}$. Habitualmente, tan sólo se ha prestado atención a los conflictos políticos protagonizados por la mano menor así como a las principales reformas $(1345,1374,1376,1379,1393 \ldots)$ introducidas en la planta del gobierno municipal. Esta dinámica, sin embargo, apenas si se ha puesto en relación con la espectacular expansión de las finanzas locales que se produce durante aquella época ni con la evolución experimentada simultáneamente por la tesorería del municipio ${ }^{102}$. Únicamente tras el avalot de 1391 contra los judíos se ponen de manifiesto las protestas, ya mencionadas, del partido popular contra la política fiscal del Consell. No obstante, casi parece obviarse la significación política que pudo tener también la regulación, en 1341, de las comisiones paritarias de auditores de cuentas, integradas por miembros de las distintas mans, elegidos ad utilitatem et comodum dicte civitatis, postpositis amore, gratia et timore cuiuslibet persone ${ }^{103}$; la consolidación definitiva de la clavaria a partir de 1360, formada por una pequeña tesorería ordinaria y una clavaria de les imposicions principal, sujeta a un cuidadoso control ${ }^{104}$; o la promulgación de ordenanzas reales destinadas a reducir el gasto municipal, especialmente por lo que se refiere al capítulo de retribuciones y salarios ${ }^{105}$.

Desgraciadamente, la bibliografía existente para el caso de Girona tampoco ha sido capaz de explicar la más que probable relación existente entre la tensión política documentada durante la primera mitad del s. XV y la progresiva evolu-

\footnotetext{
${ }^{100} \mathrm{M}$. Sánchez no ha dudado en considerar la conquista de Cerdeña, a partir de 1321, como un «punto de inflexión» en la dinámica fiscal catalana (SÁNCHEZ, «Tributos negociados», pp. 77-79).

${ }^{101}$ En este caso, la fuentes tampoco ayudan a conocer realmente lo que sucedía, tal como se desprende de una disposición real del año 1366, ordenando a los oficiales reales de Girona que no permitiesen que personas de mano menor de la ciudad se reuniesen de forma indebida e ilícita (ARNALL, Lletres reials, vol. I, pp. 508-509).

102 Véase nota 99.

103 GUILLERÉ, Llibre Verd, pp. 314-316.

${ }^{104}$ GUILLERÉ, «Fiscalité et societé», pp. 378-379.

${ }^{105}$ Aunque todavía no he podido localizar el documento original, existe una carta real de 1385 que hace mención a ciertas ordenanzas del infante Juan, entre la cuales se halla un capítulo que regulaba estrictamente el pago de salarios, retribuciones y donativos por parte de los regidores, sometiéndolo al control del Consell General (ARNALL, Lletres reials, vol. II, pp. 588-590).
} 
ción de la hacienda ${ }^{106}$. No puede pasarse por alto, sin embargo, que las finanzas siguieron siendo determinantes, hasta el punto de motivar la creación de un banco municipal. Como es sabido, durante el cuatrocientos, asistimos a numerosas tentativas (en su mayor parte fallidas) por parte de algunas poblaciones catalanas de crear taules de canvi para financiar la deuda censal: Girona fue la protagonista de uno de estos audaces intentos, tal como lo demuestra el extenso privilegio real, concedido el año 1443 per favor e utilitat de la cosa pública a la ciudad ${ }^{107}$. Tampoco puede olvidarse la normativa que regulaba el gasto ni la evolución experimentada por la figura de los auditores de cuentas: el año 1457, tan sólo documentamos la existencia de un único «oïdor de comptes major» que, como veremos posteriormente, quizás pueda identificarse con el cargo del interventor general documentado en otras villas y ciudades del principado ${ }^{108}$. Y, finalmente, otra imagen que debe retenerse es la del nutrido archivo municipal que aparece en el inventario de 1459. Un archivo donde, como hemos visto, los arcones destinados a custodiar los retiments (auditorías) realizados por los distintos administradores municipales o las cuentas presentadas por los embajadores de la universidad ocupaban un lugar destacado, junto a los pergaminos y los libros de privilegios.

Ante tantos indicios, no me parece en absoluto aventurado identificar la evolución experimentada por esta ciudad catalana con la que, paralelamente, se documenta en otros muchos lugares del país, donde los vínculos existentes entre las dinámicas política y financiera sí que resultan evidentes. Y es que, desde principios del s. XIV, las denuncias de corrupción o iniquidad fiscal condujeron a la reforma de la planta de algunos municipios, que se acompañan de la creación

${ }^{106}$ Para esta época, continúa siendo obra de referencia: SOBREQUÉS i VIDAL, S., Societat i estructura politica de la Girona medieval, Barcelona, 1975, pp. 75-136.

${ }^{107}$ JULIOL, Llibre Vermell, pp. 245-255. Probablemente, para poner en marcha esta iniciativa, las autoridades gerundenses siguieron el ejemplo de Barcelona que, en 1401, inauguraba su particular banco tras la preceptiva reunión del Consejo General de la ciudad. En esta reunión todos los miembros de la asamblea firmaron, ante el veguer real, el documento de sindicato que debía asegurar la futura solvencia de la Taula y, tras este acto, los honorables consellers ab alscuns prohomens ciutadans mercaders e menestrals se ajustaren en la casa del Consell e anarey oyr missa del Sant Sperit a Santa Eulalia, e puys anarensen a la dita lotge [donde estaba físicamente la Taula] ab VIII entre trompes e trompetes (ORTI GOST, P., «Les finances municipals de la Barcelona dels segles XIV i XV: del censal a la Taula de Canvi», en Barcelona. Quaderns d'història, 13, Barcelona 2007, pp. 257-282, cf. Manual de novells ardits vulgarment apellat Dietari del Antich Consell Barcelona, vol. I, Barcelona, 1892, p. 87). Sobre el resto de Taules de Canvi municipales documentadas en Cataluña, véase una primera aproximación general en PASSOLA, J.M., Els orígens de la banca pública: les taules de canvi municipals, Sabadell, 1999.

${ }^{108}$ Este oïdor no aparece en la reforma municipal de 1445, donde todavía se elegían tres auditores, (JULIOL, Llibre Vermell, p. 268) y sí que se contempla en la reforma de 1457 (SOBREQUÉS, Societat i estructura, p. 130). 
física de un arca común, dotada de varias cerraduras, y del establecimiento de normas precisas (órdenes de pago, recibos, auditores...) para controlar el gasto municipal ${ }^{109}$. Desde mediados del s. XIV, estos privilegios políticos también contemplan la regulación de la tesorería (clavaria) municipal, presente ya en las principales localidades del país, así como del conflictivo nombramiento de auditores de cuentas para fiscalizar la actuación de aquel y otros administradores de recursos comunitarios $^{110}$. Por último, a finales del trescientos, la progresiva complicación de la maquinaria financiera del municipio y las reiteradas acusaciones de malversación o negligencia dirigidas contra los regidores exigieron de nuevo reformas políticas, dando lugar incluso a la creación de interventores generales o, lo que es lo mismo, a la aparición de la emblemática figura del racional municipal ${ }^{111}$. Todo ello, en el marco de las flamantes casas consistoriales, en muchos casos construidas durante este último periodo ${ }^{112}$, y donde por primera vez documentamos la existencia de incipientes archivos municipales, con la correspondiente sección dedicada a custodiar los registros generados por la hacienda local ${ }^{113}$.

109 Véanse, por ejemplo, los casos de Cervera y Tárrega: TURULL RUBINAT, M. y VERDÉS PIJUAN, P., «Gobierno municipal y fiscalidad en Cataluña durante la Baja Edad Media», en Anuario de Historia del Derecho Español, 76, Madrid 2006, pp. 507-530.

110 Además de los datos que ofrece sobre los tesoreros y auditores municipales en Cataluña el clásico trabajo de FONT RIUS, «La administración financiera», pp. 220-229; véase también el ejemplo concreto que nos ofrece (así como la bibliografía que lo acompaña) J. Morelló para Reus y Valls: MORELLÓ BAGET, J., «La intervención de las cuentas municipales: la actuación de los oïdors en Reus y Valls», en D. Menjot y M. Sánchez (coord.), La fiscalité des villes au Moyen Âge (Occident méditerranéen). La gestion de l'impôt, Toulouse, 2004, pp. 259-271.

111 Sobre este cargo, documentado ya en Barcelona, Tarragona, Lérida, Manresa, Tortosa, Cervera, Balaguer, Tarrega o Reus durante la época medieval, véanse los datos que nos ofrecen los dos trabajos citados en la nota anterior así como VERDÉS PIJUAN, P., «Politiques fiscales et stratégies financières dans les villes catalanes aux XIVe et XVe siècles», en Colloque: L'impôt dans les villes de l'Occident méditerranéen (XIIIe-XVe siècle), Paris, 2005, pp. 155-171 (esp. 169-171). Resulta especialmente interesante el caso de Barcelona, donde la escribanía o "casa del racional» se convirtió en un verdadero depósito de la memoria municipal: RIERA VIADER, S., «Les fonts municipals del període 1249-1714. Guía d'investigació», en Barcelona. Quaderns d'història, 4, Barcelona 2001, pp. 239-275 (esp. 256-260).

112 PLADEVALL i FONT, A., Lart gòtic a Catalunya. Arquitectura, III. Dels palaus a les masies, Barcelona, 2003, pp. 179-195; así como los datos dispersos contenidos en pp. 46-123. En este estudio se indica que la Casa del Consell fue iniciada a principios del s. XV, en la Plaça del $\mathrm{Vi}$, aunque no he sabido hallar más datos concretos sobre los orígenes del edificio (Ibídem p. 58).

${ }^{113}$ Un ejemplo sobre los orígenes y el desarrollo de los archivos municipales en Cataluña: CURTO HOMEDES, A., «Origen i evolució de l'Arxiu de la Ciutat de Tortosa (segles XIVXVII)», en Lligall, 18, Barcelona 2001, pp. 121-146. Véase también los datos que nos ofrece, para el caso de Barcelona, el estudio de S. Riera citado en la nota anterior así como una panorámica de la evolución posterior de estos archivos durante época moderna, que nos ofrece: PÉREZ LATRE, M., «Sercar, ordenar y fer inventari y índex». Sobre arxius i institucions a Catalunya (segles XVI-XVII», en Lligall, 22, Barcelona, 2004, pp. 73-120. 
No cabe duda de que, al igual que sucedía en el ámbito de la fiscalidad, la creación de todos estos elementos financieros (la caja común, el tesorero, los auditores de cuentas, el racional y el archivo) respondían tanto a unas necesidades objetivas del municipio como al incremento de la conciencia colectiva y de la cultura política de la población urbana. Una cultura que, también en este caso, tiene su máxima expresión en el discurso formulado por los distintos contendientes políticos en los momentos de conflicto financiero, léase cuando los regidores eran acusados de negligencia y/o corrupción.

Como he apuntado, pese a disponer de algunas referencias indirectas a su existencia, hasta el momento no he conseguido documentar claramente episodios de este tipo en Girona ${ }^{114}$. Sin embargo, no creo que los argumentos utilizados por los sectores populares (o el bando político de turno) para poner en duda la legitimidad del gobierno municipal en esta ciudad difirieran mucho de los que se documentan en otras poblaciones. Cabe destacar que, en ocasiones, conocemos las denuncias formuladas contra las autoridades municipales gracias al eco que se hacía de ellas la monarquía (o el señor), especialmente desde finales del s. XIV, coincidiendo con la creciente resistencia a satisfacer sus demandas fiscales. Como ya he apuntado, numerosos comisarios reales fueron enviados a las ciudades y villas catalanas durante esta época para intervenir el gobierno municipal, documentándose también algunos permisos para que los opositores pudieran reunirse, recaudar tallas y financiar embajadas a la corte ${ }^{115}$. Lógicamente, este hecho era considerado por los regidores afectados como un grave atentado contra las libertades políticas de la universidad e incluso contra la integridad de la comunidad, máxime cuando las acusaciones de negligencia y corrupción («desgobiernos») eran totalmente infundadas y lo único que buscaban era romper la necesaria concordia social. Al menos, esto es lo que se refiere en las fuentes municipales, donde también se dedican todo tipo de descalificativos tanto a los representantes reales/señoriales como a los integrantes del bando contrario, habitualmente del partido popular. Las referencias a la baja condición de los con-

\footnotetext{
${ }^{114}$ Vid. nota 91.

${ }^{115}$ Especialmente interesante resulta el caso de Lleida, donde se documentan repetidos conflictos entre 1388 y 1413: GRAS DE ESTEVA, R., Història de la Paeria, Lleida, 1988 (1909), PP. 162-170; FERRER MALLOL, «Un memorial de greuges», pp. 293-314. Aunque, sin lugar a dudas, el ejemplo más conocido es el de la ciudad de Barcelona, donde además se ha podido documentar perfectamente el discurso formulado tanto por los miembros de la Biga como por los de la Busca: BATLLE GALLART, C., «La ideología de la Busca», en Estudios de Historia Moderna, 5, Barcelona 1955, pp. 167-195. Para conocer más detalles sobre el conflicto entre la Biga y la Busca, especialmente por lo que se refiere a las cuestiones financieras, véase de la misma autora: BATLLE, La crisis social, vol. I, pp.190-194, 225-230, 295-296.
} 
trincantes, a su incapacidad para gobernar, a los muchos vicios que exhibían así como al peligro que entrañaba la muchedumbre que les secundaba constituyen lugares comunes en el discurso del poder establecido, quien sabe si inspirado en alguno de los textos contenidos en el Dotzè del Crestià u otra obra coetánea ${ }^{116}$.

Por la repercusión que tuvieron, también en Girona, no puedo acabar sin recordar que estos argumentos se oyeron con especial virulencia en la Casa del Consell de Barcelona, durante el s. XV, en el contexto de las enconadas luchas políticas que enfrentaron la Biga y la Busca ${ }^{117}$. Unas palabras que, a diferencia de lo que sucedía a finales del s. XIII, eran pronunciadas ya por elegantes consellers vestidos con suntuosas gramallas, y a la luz de ricas vidrieras donde aparecían las virtudes cardinales (prudencia, justicia, templanza y fortaleza) así como las alegóricas escenas del Juicio Final ${ }^{118}$.

\section{CONSIDERACIONES FINALES}

Hasta aquí mi reflexión sobre la dinámica fiscal y financiera que se documenta en las ciudades y villas de Cataluña durante la época bajomedieval. No sé si habré conseguido mi propósito, que era el de mostrar cuáles fueron algunas de las categorías que se instalaron en el imaginario colectivo de las comunidades locales. Pero, como mínimo, espero haber proporcionado algunos elementos de juicio que nos permitan encarar con mayores garantías el estudio del proceso de configuración de la identidad urbana en el principado (especialmente en el realengo) durante dicho periodo. Como hemos visto, a finales del s. XIV, conceptos como servicio, honor, libertad, solidaridad, justicia, prosperidad, diligencia, honradez, aptitud, orden o concordia habían adquirido ya una enorme significación para los habitantes de la urbes catalanas, y con toda seguridad obras como las de Francesc Eiximenis contribuyeron a consolidarlos definitivamente, sobre todo, en el pensamiento (y el discurso) de sus clases dirigentes. Ahora bien, ninguno de estos valores era consubstancial a la comunidad local, sino que fueron

\footnotetext{
116 Además de las muchas referencias a los argumentos utilizados por la Biga y la Busca en Barcelona, durante el s. XV, que pueden hallarse en los trabajos de C. Batlle citados en la nota anterior, he de remitirme también a los detalles sobre las estrategias discursivas que se documentan en Cervera durante dicha centuria (vid. nota 48).

117 Vid. nota supra.

${ }^{118}$ Más detalles sobre las vidrieras citadas y otros elementos ornamentales que completaban la escenografía política de la casa consistorial de Barcelona, en: DURAN i SANPERE, A., Barcelona i la seva història. L'art i la cultura, Barcelona, 1975, pp. 232-259. Recuérdese también, la existencia de los célebres retablos de los paers de Lleida o el de los consellers de Barcelona: sobre este último, especialmente interesantes resultan las reflexiones de RAVENTÓS i FREIXA, J., «La Verge dels Consellers i el Retaule dels Blanquers. Art i política a Barcelona en la cursi del segle XV», en Pedralbes, 13/2, Barcelona 1993, pp. 429-433.
} 
afianzándose progresivamente como consecuencia de determinadas circunstancias históricas, entre las que se encontraban la construcción de una hacienda municipal. Las demandas reales y el endeudamiento censal nos han permitido vislumbrar como empezó a tomar forma la universitas del s. XIII y como adquirió su carta de naturaleza durante el s. XIV, gracias a las libertades que le fueron concedidas por la autoridad real/señorial. Asimismo, la recaudación de tallas e imposiciones nos han permitido observar como fue configurándose la noción de vecindad o ciudadanía durante el mismo periodo, y como el espacio urbano acabó estando mediatizado por la fiscalidad municipal. Finalmente, la administración del erario municipal ha servido para mostrar la progresiva aculturación política de la población urbana en el principado, tal como se desprende de la compleja estructura financiera levantada así como por los mecanismos de control implementados por el municipio. Todo ello, sin embargo, en un contexto de latente conflicto, que estalla con violencia durante el s. XV como consecuencia, en gran parte, de las dificultades económicas de los consistorios y de la divergencia de intereses entre los distintos actores que concurrían en el escenario político urbano. Precisamente, es durante este último periodo cuando se aprecia de forma nítida el «modelo de identidad urbana» tradicionalmente atribuido a la ciudad catalana medieval, habida cuenta de que es entonces cuando los dirigentes municipales formulan un discurso más elaborado y ponen en escena toda una serie de manifestaciones simbólicas y rituales encaminadas a legitimar su actuación y la reforzar la conciencia colectiva, el orgullo cívico y, en definitiva, la lealtad de la comunidad. Tal como veíamos al inicio de este trabajo, una clara muestra de este modelo nos la ofrecen los inventarios de la Casa del Consell de Girona, donde hemos hallado los elementos necesarios para hilvanar la presente estudio y aproximarnos a una de las caras de la identidad urbana en Cataluña que, recordémoslo una vez más, no fue nunca monolítica ni tampoco inmune al paso del tiempo. 